Article

\title{
Spatial Distribution and Chemical Composition of Road Dust in Two High-Altitude Latin American Cities ${ }^{\dagger}$
}

\author{
Sebastián Vanegas ${ }^{1}$ D , Erika M. Trejos ${ }^{2}$, Beatriz H. Aristizábal ${ }^{2}$, Guilherme M. Pereira ${ }^{3}$, Julio M. Hernández ${ }^{4}$, \\ Jorge Herrera Murillo ${ }^{4}$, Omar Ramírez ${ }^{5, * \mathbb{D}}$, Fulvio Amato ${ }^{6}$, Luis F. O. Silva ${ }^{7}$, Néstor Y. Rojas ${ }^{1}$, Carlos Zafra ${ }^{8}$ (D) \\ and Jorge E. Pachón $9, *$ (D)
}

check for updates

Citation: Vanegas, S.; Trejos, E.M.; Aristizábal, B.H.; Pereira, G.M.; Hernández, J.M.; Murillo, J.H.; Ramírez, O.; Amato, F.; Silva, L.F.O.; Rojas, N.Y.; et al. Spatial Distribution and Chemical Composition of Road Dust in Two High-Altitude Latin American Cities. Atmosphere 2021, 12, 1109. https://doi.org/10.3390/ atmos12091109

Academic Editor: Aurelie Charron

Received: 20 July 2021

Accepted: 25 August 2021

Published: 28 August 2021

Publisher's Note: MDPI stays neutral with regard to jurisdictional claims in published maps and institutional affiliations.

Copyright: (C) 2021 by the authors Licensee MDPI, Basel, Switzerland. This article is an open access article distributed under the terms and conditions of the Creative Commons Attribution (CC BY) license (https:// creativecommons.org/licenses/by/ $4.0 /)$.
1 Department of Chemical and Environmental Engineering, Universidad Nacional de Colombia-Sede Bogotá, Bogotá 111321, Colombia; jovanegasg@unal.edu.co (S.V.); nyrojasr@unal.edu.co (N.Y.R.)

2 Hydraulic Engineering and Environmental Research Group, Universidad Nacional de Colombia-Sede Manizales, Manizales 170004, Colombia; emtrejosz@unal.edu.co (E.M.T.); bharistizabalz@unal.edu.co (B.H.A.)

3 Institute of Chemistry, Universidade de São Paulo, São Paulo 05580-000, Brazil; guilherme.martins.pereira@usp.br

4 Environmental Analysis Laboratory, Environmental Sciences School, Universidad Nacional de Costa Rica, Heredia 40101, Costa Rica; jucemuhe@gmail.com (J.M.H.); jorge.herrera.murillo@una.cr (J.H.M.)

5 Environmental Engineering Program, Universidad Militar Nueva Granada, Cajicá-Zipaquirá 250247, Colombia

6 Institute for Environmental Assessment and Water Research (IDÆA), Spanish National Research Council (CSIC), 08034 Barcelona, Spain; fulvio.amato@idaea.csic.es

7 Department of Civil and Environmental Engineering, Universidad de la Costa, Barranquilla 080002, Colombia; lsilva8@cuc.edu.co

8 Environmental Engineering Research Group-GIIAUD, Universidad Distrital Francisco José de Caldas, Bogotá 110321, Colombia; czafra@udistrital.edu.co

9 Centro Lasallista de Investigación y Modelación Ambiental_CLIMA, Universidad de La Salle, Bogotá 111711, Colombia

* Correspondence: omar.ramirez@unimilitar.edu.co (O.R.); jpachon@unisalle.edu.co (J.E.P.); Tel.: +57-301-2414281 (O.R.); +57-310-3173756 (J.E.P.)

$+\quad$ This paper is dedicated to the memory of Professor Beatriz H. Aristizábal.

Abstract: Road dust (RD) resuspension is one of the main sources of particulate matter in cities with adverse impacts on air quality, health, and climate. Studies on the variability of the deposited $\mathrm{PM}_{10}$ fraction of $\mathrm{RD}\left(\mathrm{RD}_{10}\right)$ have been limited in Latin America, whereby our understanding of the central factors that control this pollutant remains incomplete. In this study, forty-one $\mathrm{RD}_{10}$ samples were collected in two Andean cities (Bogotá and Manizales) and analyzed for ions, minerals, and trace elements. $\mathrm{RD}_{10}$ levels varied between $1.8-45.7 \mathrm{mg} / \mathrm{m}^{2}$, with an average of $11.8 \mathrm{mg} / \mathrm{m}^{2}$, in Bogotá and between $0.8-26.7 \mathrm{mg} / \mathrm{m}^{2}$, with an average of $5.7 \mathrm{mg} / \mathrm{m}^{2}$, in Manizales. Minerals were the most abundant species in both cities, with a fraction significantly larger in Manizales (38\%) than Bogotá $(9 \%)$. The difference could be explained mainly by the complex topography and the composition of soil derived from volcanic ash in Manizales. The volcanic activity was also associated with $\mathrm{SO}_{4}{ }^{-2}$ and $\mathrm{Cl}^{-}$. Enrichment factors and principal component analysis were conducted to explore potential factors associated to sources of $\mathrm{RD}_{10}$. Elements such as $\mathrm{Cu}, \mathrm{Pb}, \mathrm{Cr}, \mathrm{Ni}, \mathrm{V}, \mathrm{Sb}$, and Mo were mainly associated with exhaust and non-exhaust traffic emissions.

Keywords: $\mathrm{PM}_{10}$; dust resuspension; sediment load; non-exhaust emissions; chemical profile; enrichment factors; Colombia

\section{Introduction}

Particulate matter (PM) emitted by road transport can be released both from the exhaust pipe, as a result of incomplete fuel combustion, and from non-exhaust processes [1] Exhaust particles have shown a trend of decreasing emissions due to stringent tailpipe standards, better fuel quality, and migration towards zero- or low-emission vehicles in 
recent decades [2]. However, detailed information concerning non-exhaust PM emissions is still relatively limited in developing countries, particularly in Latin America, where there is not enough knowledge regarding physicochemical characteristics of PM, its spatial distribution, and associated adverse health effects, among other variables.

Non-exhaust emissions have been identified as one of the most significant sources of air pollution in urban environments due to their contribution of coarse, fine, and ultrafine particles [1,3-6]. These emissions are constituted by direct releases of particles due to abrasion processes, including tire, brake, clutch, and road wear [7-9]. They also include the resuspension of road dust, namely PM emitted from natural and anthropogenic sources, deposited on the road surface, and resuspended as a result of vehicular turbulence and the action of the wind [2].

Road dust is composed mainly of crustal dust and soil material, but also of particles derived from several anthropogenic sources, such as traffic, industrial emissions, quarries, and construction activities, among others $[6,10,11]$. Therefore, the chemical composition of road dust is variable and is associated with the characteristics of the emission sources. This includes abundant crust elements, such as $\mathrm{Al}, \mathrm{Fe}, \mathrm{Mg}$, $\mathrm{Na}, \mathrm{P}$, and $\mathrm{Ti}$, among others, but also hazardous components such as $\mathrm{Pb}, \mathrm{V}, \mathrm{Cd}, \mathrm{Cu}, \mathrm{Sb}$, and polycyclic aromatic hydrocarbons (PAHs). The latter ones generate adverse effects on human health, especially on the cardiorespiratory system [12]. Road dust loadings, as well as their chemical speciation, vary geographically depending on parameters such as meteorology, geology of the region, and even the type of pavement sampled $[13,14]$.

Some studies have investigated the association of road dust particles and mortality from cardiorespiratory diseases and other causes. Researchers have found that an incremental increase of particles related to road dust resuspension can increase mortality risk by $4.0 \%$, higher than the observed for vehicle exhaust [15]. Other studies have reported a significant daily mortality because of an increase of $10 \mu \mathrm{g} / \mathrm{m}^{3}$ of particles related to road dust in Stockholm [16]. Lastly, chemical species associated with road dust and mineral resuspension, such as $\mathrm{SiO}_{2}, \mathrm{Ca}, \mathrm{Fe}$, and $\mathrm{Ti}$, have shown deleterious health effects $[17,18]$. Consequently, studying the loadings and the chemical composition of road dust, as well as its spatial variability, is crucial to identify the origin of the PM, to formulate mitigation measures and to identify potential adverse effects on the population.

Studies on loadings and chemical characterization of particles below $10 \mu \mathrm{m}$ from road dust $\left(\mathrm{PM}_{10}\right.$ but termed $\mathrm{RD}_{10}$ in this study) have been carried out in several cities. For example, Alves et al. [7] used a portable resuspension chamber to collect road dust from five main roads in Oporto and an urban tunnel in Braga, Portugal. Researchers reported dust loadings of $0.48 \pm 0.39 \mathrm{mg} \mathrm{PM}_{10} / \mathrm{m}^{2}$ for asphalt paved roads. Furthermore, they found that crustal and anthropogenic elements, associated with tire and brake wear, dominated the inorganic fraction. Vlasov et al. [19] analyzed potentially toxic elements (PTEs) in road dust in Moscow, finding that the main pollutants of the $\mathrm{PM}_{10}$ fraction included $\mathrm{Sb}, \mathrm{Zn}, \mathrm{W}, \mathrm{Sn}, \mathrm{Bi}, \mathrm{Cd}, \mathrm{Cu}, \mathrm{Pb}$, and $\mathrm{Mo}$. They concluded that particles were most contaminated in the central part of the city due to the large number of cars and traffic congestions. Zhang et al. [20] analyzed a total of 64 dust samples collected from five urban roads and four parks in Tianjin, China to determine the size distribution and elemental composition of the $\mathrm{PM}_{10}$ fraction. The researchers found that crustal elements accounted for $30.14 \%$ of the $\mathrm{PM}_{10}$ fractions and the most abundant trace elements were $\mathrm{Zn}, \mathrm{Mn}$, and $\mathrm{Cu}$ (range, 277 to $874 \mathrm{mg} / \mathrm{kg}$ ). Pant et al. [21] obtained road dust samples collected at two sites in Birmingham, UK and one site in New Delhi, India. They found that dust loadings were found to be much higher for New Delhi $\left(72.9 \pm 24.3 \mathrm{mg} / \mathrm{m}^{2}\right)$ compared to Birmingham (range, $9.34 \pm 5.56$ to $12.1 \pm 9.3 \mathrm{mg} / \mathrm{m}^{2}$ ). In addition, $\mathrm{Cu}$ was found to be a factor significantly associated with oxidative potential in the $\mathrm{PM}_{10}$ fraction.

Although some emission inventories have recognized resuspended road dust as one of the most significant sources of PM in urban centers [22], research on $\mathrm{RD}_{10}$ conducted in Latin American countries has been scarce. Pachón et al. [23] studied influencing factors of road dust in Bogotá, finding that meteorology, land use, traffic characteristics, and road 
conditions determine $\mathrm{RD}_{10}$ levels in the city. Ramírez et al. [24] characterized inorganic compounds (water-soluble ions, major and trace elements, organic and elemental carbon) and estimated source contributions to the $\mathrm{PM}_{10}$ fraction of road dust sampled in Bogotá, the capital of Colombia. Crustal elements were the most abundant species, accounting for $49-62 \%$ of the $\mathrm{PM}_{10}$ fraction, followed by OC (13-29\%), water-soluble ions (1.4-3.8\%), EC $(0.8-1.9 \%)$, and trace elements $(0.2-0.5 \%)$. On the other hand, Ramírez et al. [25] evaluated road dust in Barranquilla, a major industrial city in the Caribbean region, finding that the major elements, including $\mathrm{Al}, \mathrm{Ca}, \mathrm{Fe}, \mathrm{K}, \mathrm{Mg}, \mathrm{Na}$, and $\mathrm{S}$, were the most abundant species, accounting for $23 \% \pm 18 \%$ of the mass of thoracic particles.

The objective of this paper was to show an analysis of the spatial distribution and chemical composition of road dust in two high-altitude Latin American cities. This study was conducted in two cities in Colombia (Bogotá and Manizales), located in the Andean mountains at $2000 \mathrm{~m}$ above sea level (m.a.s.l.). The cities were selected for presenting different demographic conditions, transportation patterns, industrial dynamics, and pollution levels. The aims of the research were (i) to determine the $\mathrm{RD}_{10}$ load in each city according to land use, (ii) to evaluate the spatial distribution and the chemical composition of $\mathrm{RD}_{10}$ in Bogota and Manizales, and (iii) to explore potential factors associated to sources of $\mathrm{RD}_{10}$ for the two cities mentioned.

\section{Materials and Methods}

\subsection{Sampling Locations}

Bogotá is the capital of Colombia and the largest city in the country (population of 8.1 million), located in the South America Andes Cordillera at an altitude of 2640 m.a.s.l. (Figure 1). The urban region has an approximate area of $420 \mathrm{~km}^{2}$ and a high population density, 17,700 inhabitants per $\mathrm{km}^{2}$ [24]. Meteorological conditions in Bogotá are characterized by having an average temperature of $15^{\circ} \mathrm{C}$ and average annual precipitation of $844 \mathrm{~mm}$. Winds from NE-E and SE-E predominate, with average speeds of $1.5-3.5 \mathrm{~m} / \mathrm{s}$. The trade winds reach the city between June and August, favoring pollutant dispersion. The city has a high motorization rate, 313 vehicles per 1000 inhabitants in the year of 2018 [26]. The city's vehicle fleet in 2018 was composed of 2.4 million vehicles, in which $47 \%$ were passenger cars, $25 \%$ pick-up trucks, $22 \%$ motorcycles, $3 \%$ heavy-duty cargo fleet, $2 \%$ taxis, and $1.9 \%$ collective transport buses [27]. Private vehicles and motorcycles use mainly gasoline, taxis use gasoline and vehicular natural gas (NG), buses use diesel and $\mathrm{NG}$, and heavy vehicles use predominantly diesel as fuel.

Bogotá has a mix of industries, such as manufacturing, chemical, plastics, food and beverages, metallurgy, exploitation of quarries, and mining (nonmetallic) areas, among others. This sector has an intensive use of fossil fuels for goods production and transportation. The industries are located both within the urban area and at nearby municipalities, generating land-use and environmental conflicts [28]. Frequently, PM exceeds national air quality standards in the southern and western areas of the city, given the emission sources, and local and meteorological conditions [24].

Manizales is a medium-sized Andean city (population of 434,403 inhabitants) [29], located in the central-west of Colombia on the western slope of the Cordillera Central at an altitude of 2150 m.a.s.l. [30] (Figure 1). The urban region has an approximate area of $54 \mathrm{~km}^{2}$ [29] and high population density ( 7504 inhabitants per $\mathrm{km}^{2}$ in the urban area). Meteorological conditions in Manizales are characterized by a high annual precipitation $(1670 \mathrm{~mm})$ with a high spatial variability. The diurnal temperature profile ranges between $12-24{ }^{\circ} \mathrm{C}$, high relative humidity between $69-86 \%$, and low wind speeds $(\leq 2 \mathrm{~m} / \mathrm{s})$. These meteorological conditions enhance minimum dispersion of pollutants in the urban area [31,32]. Local atmospheric chemistry is influenced by proximity to the Nevado del Ruiz volcano (located approximately $28 \mathrm{~km}$ from the southeast of Manizales and $140 \mathrm{~km}$ from the northwest of Bogotá), one of the most active in Latin America, registering significant activity since 2010 with daily $\mathrm{SO}_{2}$ and ash emission episodes [33]. Valley-mountain 
wind circulation patterns in the city are characterized as ascending by day and descending by night $[30,31]$, with possible transport of volcanic emissions during downslope wind.

Manizales has a high motorization rate, 455.2 vehicles per 1000 inhabitants in the year of 2018 [31,34]. The city's vehicle fleet in 2017 was composed of 169,142 vehicles, in which $48.3 \%$ were passenger cars, $47.1 \%$ motorcycles, $1.4 \%$ taxis, $1.5 \%$ collective transport buses, and $1.7 \%$ pick-up trucks. Private vehicles and motorcycles use gasoline, taxis use gasoline and NG, and buses and heavy vehicles use diesel as fuel. Manizales has a diverse industrial sector of food and beverages, chemical, plastics, metallurgy, foundry, and minerals, among others. These industries use natural gas, coal, and diesel as fuels [32].
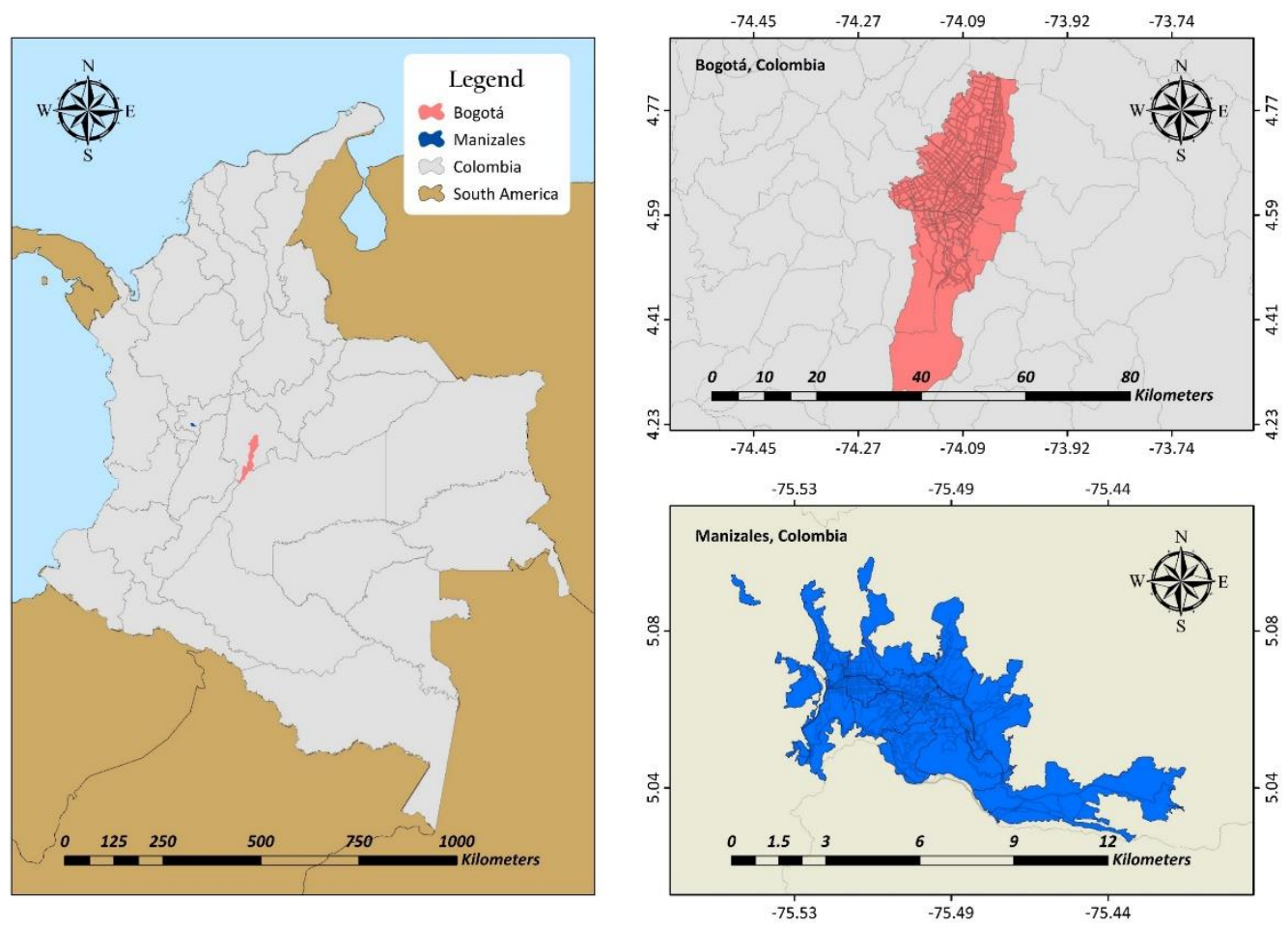

Figure 1. Location of the study cities-Bogotá and Manizales, Colombia.

\subsection{Road Dust Samplings}

A total of 41 samples were obtained from the two cities, 20 samplings were carried out in Bogotá and 21 in Manizales. Road dust sampling was conducted in dry weather and at least $48 \mathrm{~h}$ after a precipitation event. This condition guarantees that particles are mobilized and not retained by the surface humidity [35]. Field campaigns were carried out between December 2017 and March 2018 in Bogotá, and between July and September 2019 in Manizales (Table 1). As a result of the closeness with the equator (latitudes between 4.5 and 5.1 degrees north for Bogotá and Manizales, respectively), the seasonal variations of temperature and solar radiation between these two cities in question are small, and even negligible if the length of the day is considered. Of all samples, 23 were collected in areas of the cities where commercial activities predominate (average conditions typical of each city) -7 in Bogotá and 16 in Manizales; nine samples were taken in sites of interest such as industrial areas - 6 in Bogotá and 3 in Manizales; nine samples were taken in sites of interest with little activity, such as residential areas-7 in Bogotá and 2 in Manizales. 
Table 1. Average loading of $\mathrm{RD}_{10}$ at each location.

\begin{tabular}{|c|c|c|c|c|c|}
\hline ID Point & Length & Latitude & Sampling Date & Classification & $\mathrm{RD}_{10}\left(\mathrm{mg} / \mathrm{m}^{2}\right)$ \\
\hline \multicolumn{6}{|c|}{ Bogotá } \\
\hline 1 & $74^{\circ} 03^{\prime} 59.07^{\prime \prime} \mathrm{W}$ & $4^{\circ} 45^{\prime} 34.48^{\prime \prime} \mathrm{N}$ & 19 December 2017 & Commercial Land Use & 3.26 \\
\hline 2 & $74^{\circ} 01^{\prime} 28.05^{\prime \prime} \mathrm{W}$ & $4^{\circ} 45^{\prime} 21.12^{\prime \prime} \mathrm{N}$ & 19 December 2017 & Residential Land Use & 7.04 \\
\hline 3 & $74^{\circ} 01^{\prime} 56.41^{\prime \prime} \mathrm{W}$ & $4^{\circ} 43^{\prime} 12.28^{\prime \prime} \mathrm{N}$ & 20 December 2017 & Residential Land Use & 14.31 \\
\hline 4 & $74^{\circ} 02^{\prime} 50.84^{\prime \prime} \mathrm{W}$ & $4^{\circ} 41^{\prime} 14.78^{\prime \prime} \mathrm{N}$ & 20 December 2017 & Residential Land Use & 18.92 \\
\hline 5 & $74^{\circ} 03^{\prime} 58.63^{\prime \prime} \mathrm{W}$ & $4^{\circ} 38^{\prime} 22.69^{\prime \prime} \mathrm{N}$ & 22 December 2017 & Commercial Land Use & 7.06 \\
\hline 6 & $74^{\circ} 04^{\prime} 14.20^{\prime \prime} \mathrm{W}$ & $4^{\circ} 39^{\prime} 26.73^{\prime \prime} \mathrm{N}$ & 27 January 2018 & Commercial Land Use & 10.33 \\
\hline 7 & $74^{\circ} 05^{\prime} 38.62^{\prime \prime} \mathrm{W}$ & $4^{\circ} 41^{\prime} 18.01^{\prime \prime} \mathrm{N}$ & 26 January 2018 & Commercial Land Use & 4.60 \\
\hline 8 & $74^{\circ} 07^{\prime} 25.07^{\prime \prime} \mathrm{W}$ & $4^{\circ} 43^{\prime} 27.55^{\prime \prime} \mathrm{N}$ & 26 March 2018 & Commercial Land Use & 45.75 \\
\hline 9 & $74^{\circ} 09^{\prime} 11.51^{\prime \prime} \mathrm{W}$ & $4^{\circ} 40^{\prime} 31.39^{\prime \prime} \mathrm{N}$ & 26 January 2018 & Industrial Land Use & 1.82 \\
\hline 10 & $74^{\circ} 07^{\prime} 25.32^{\prime \prime} \mathrm{W}$ & $4^{\circ} 39^{\prime} 07.38^{\prime \prime} \mathrm{N}$ & 26 January 2018 & Industrial Land Use & 2.41 \\
\hline 11 & $74^{\circ} 07^{\prime} 11.76^{\prime \prime} \mathrm{W}$ & $4^{\circ} 38^{\prime} 07.65^{\prime \prime} \mathrm{N}$ & 24 January 2018 & Industrial Land Use & 7.08 \\
\hline 12 & $74^{\circ} 05^{\prime} 52.42^{\prime \prime} \mathrm{W}$ & $4^{\circ} 37^{\prime} 33.33^{\prime \prime} \mathrm{N}$ & 24 January 2018 & Industrial Land Use & 8.35 \\
\hline 13 & $74^{\circ} 04^{\prime} 36.13^{\prime \prime} \mathrm{W}$ & $4^{\circ} 36^{\prime} 29.91^{\prime \prime} \mathrm{N}$ & 22 December 2017 & Commercial Land Use & 12.07 \\
\hline 14 & $74^{\circ} 06^{\prime} 01.31^{\prime \prime} \mathrm{W}$ & $4^{\circ} 36^{\prime} 11.21^{\prime \prime} \mathrm{N}$ & 21 December 2017 & Residential Land Use & 9.40 \\
\hline 15 & $74^{\circ} 08^{\prime} 13.84^{\prime \prime} \mathrm{W}$ & $4^{\circ} 35^{\prime} 48.87^{\prime \prime} \mathrm{N}$ & 23 January 2018 & Industrial Land Use & 23.14 \\
\hline 16 & $74^{\circ} 10^{\prime} 06.66^{\prime \prime} \mathrm{W}$ & $4^{\circ} 37^{\prime} 47.06^{\prime \prime} \mathrm{N}$ & 3 March 2018 & Residential Land Use & 21.15 \\
\hline 17 & $74^{\circ} 10^{\prime} 38.49^{\prime \prime} \mathrm{W}$ & $4^{\circ} 35^{\prime} 51.84^{\prime \prime} \mathrm{N}$ & 27 January 2018 & Industrial Land Use & 6.05 \\
\hline 18 & $74^{\circ} 07^{\prime} 33.38^{\prime \prime} \mathrm{W}$ & $4^{\circ} 34^{\prime} 09.98^{\prime \prime} \mathrm{N}$ & 25 January 2018 & Commercial Land Use & 10.65 \\
\hline 19 & $74^{\circ} 05^{\prime} 14.33^{\prime \prime} \mathrm{W}$ & $4^{\circ} 34^{\prime} 11.51^{\prime \prime} \mathrm{N}$ & 25 January 2018 & Residential Land Use & 16.71 \\
\hline 20 & $74^{\circ} 07^{\prime} 02.07^{\prime \prime} \mathrm{W}$ & $4^{\circ} 31^{\prime} 00.78^{\prime \prime} \mathrm{N}$ & 27 March 2018 & Residential Land Use & 6.04 \\
\hline \multicolumn{6}{|c|}{ Manizales } \\
\hline 1 & $75^{\circ} 27^{\prime} 05.00^{\prime \prime} \mathrm{W}$ & $5^{\circ} 01^{\prime} 40.58^{\prime \prime} \mathrm{N}$ & 2 September 2019 & Industrial Land Use & 26.75 \\
\hline 2 & $75^{\circ} 27^{\prime} 04.86^{\prime \prime} \mathrm{W}$ & $5^{\circ} 01^{\prime} 58.84^{\prime \prime} \mathrm{N}$ & 20 August 2019 & Industrial Land Use & 11.72 \\
\hline 3 & $75^{\circ} 27^{\prime} 41.15^{\prime \prime} \mathrm{W}$ & $5^{\circ} 02^{\prime} 10.10^{\prime \prime} \mathrm{N}$ & 2 September 2019 & Industrial Land Use & 0.77 \\
\hline 4 & $75^{\circ} 27^{\prime} 56.27^{\prime \prime} \mathrm{W}$ & $5^{\circ} 01^{\prime} 55.02^{\prime \prime} \mathrm{N}$ & 31 July 2019 & Mixed Land Use & 8.54 \\
\hline 5 & $75^{\circ} 27^{\prime} 59.94^{\prime \prime} \mathrm{W}$ & $5^{\circ} 02^{\prime} 02.87^{\prime \prime} \mathrm{N}$ & 30 August 2019 & Residential Land Use & 2.52 \\
\hline 6 & $75^{\circ} 28^{\prime} 52.54^{\prime \prime} \mathrm{W}$ & $5^{\circ} 02^{\prime} 01.90^{\prime \prime} \mathrm{N}$ & 28 August 2019 & Mixed Land Use & 1.74 \\
\hline 7 & $75^{\circ} 29^{\prime} 01.39^{\prime \prime} \mathrm{W}$ & $5^{\circ} 02^{\prime} 49.34^{\prime \prime} \mathrm{N}$ & 9 August 2019 & Mixed Land Use & 1.96 \\
\hline 8 & $75^{\circ} 28^{\prime} 54.88^{\prime \prime} \mathrm{W}$ & $5^{\circ} 03^{\prime} 05.36^{\prime \prime} \mathrm{N}$ & 8 August 2019 & Mixed Land Use & 7.19 \\
\hline 9 & $75^{\circ} 29^{\prime} 24.04^{\prime \prime} \mathrm{W}$ & $5^{\circ} 03^{\prime} 07.42^{\prime \prime} \mathrm{N}$ & 28 August 2019 & Residential Land Use & 2.22 \\
\hline 10 & $75^{\circ} 29^{\prime} 12.30^{\prime \prime} \mathrm{W}$ & $5^{\circ} 03^{\prime} 27.14^{\prime \prime} \mathrm{N}$ & 9 August 2019 & Mixed Land Use & 2.72 \\
\hline 11 & $75^{\circ} 29^{\prime} 38.04^{\prime \prime} \mathrm{W}$ & $5^{\circ} 03^{\prime} 35.71^{\prime \prime} \mathrm{N}$ & 30 August 2019 & Mixed Land Use & 3.17 \\
\hline 12 & $75^{\circ} 30^{\prime} 06.37^{\prime \prime} \mathrm{W}$ & $5^{\circ} 03^{\prime} 50.11^{\prime \prime} \mathrm{N}$ & 20 August 2019 & Mixed Land Use & 2.73 \\
\hline 13 & $75^{\circ} 29^{\prime} 55.54^{\prime \prime} \mathrm{W}$ & $5^{\circ} 04^{\prime} 12.86^{\prime \prime} \mathrm{N}$ & 22 August 2019 & Mixed Land Use & 3.57 \\
\hline 14 & $75^{\circ} 30^{\prime} 20.88^{\prime \prime} \mathrm{W}$ & $5^{\circ} 03^{\prime} 57.53^{\prime \prime} \mathrm{N}$ & 6 August 2019 & Mixed Land Use & 6.46 \\
\hline 15 & $75^{\circ} 30^{\prime} 38.84^{\prime \prime} \mathrm{W}$ & $5^{\circ} 04^{\prime} 04.84^{\prime \prime} \mathrm{N}$ & 22 August 2019 & Mixed Land Use & 1.43 \\
\hline 16 & $75^{\circ} 30^{\prime} 55.37^{\prime \prime} \mathrm{W}$ & $5^{\circ} 04^{\prime} 04.19^{\prime \prime} \mathrm{N}$ & 1 August 2019 & Mixed Land Use & 7.14 \\
\hline 17 & $75^{\circ} 30^{\prime} 54.04^{\prime \prime} \mathrm{W}$ & $5^{\circ} 04^{\prime} 13.44^{\prime \prime} \mathrm{N}$ & 28 August 2019 & Mixed Land Use & 4.16 \\
\hline 18 & $75^{\circ} 31^{\prime} 00.55^{\prime \prime} \mathrm{W}$ & $5^{\circ} 04^{\prime} 08.76^{\prime \prime} \mathrm{N}$ & 6 August 2019 & Mixed Land Use & 5.92 \\
\hline 19 & $75^{\circ} 30^{\prime} 20.88^{\prime \prime} \mathrm{W}$ & $5^{\circ} 04^{\prime} 07.18^{\prime \prime} \mathrm{N}$ & 8 August 2019 & Mixed Land Use & 6.52 \\
\hline 20 & $75^{\circ} 31^{\prime} 29.75^{\prime \prime} \mathrm{W}$ & $5^{\circ} 04^{\prime} 17.44^{\prime \prime} \mathrm{N}$ & 1 August 2019 & Mixed Land Use & 7.53 \\
\hline 21 & $75^{\circ} 31^{\prime} 51.10^{\prime \prime} \mathrm{W}$ & $5^{\circ} 03^{\prime} 21.28^{\prime \prime} \mathrm{N}$ & 6 August 2019 & Mixed Land Use & 5.03 \\
\hline
\end{tabular}


A dry dust sampler designed at the Spanish National Research Council (CSIC) was used in the field campaigns. A description of the instrument is available elsewhere [8,35]. Briefly, the instrument consists of a PVC deposition chamber followed by a stainless steel elutriation filter designed to allow passage to only $\mathrm{PM}_{10}$-grade material [23]. Road sediments from the pavement of the active traffic lanes were sampled by suction (in a total area of $3.0 \mathrm{~m}^{2}$ divided into three sections of $1.0 \mathrm{~m}^{2}$ each), using a vacuum pump (a $30 \mathrm{~min}$ sampling was performed at each section with an air flow of $25 \pm 2.5 \mathrm{~L} / \mathrm{min}$ ) powered by a field generator (located at some distance downwind with respect to the sampling area). These sediments were immediately resuspended in the deposition chamber. The particles that were small and/or light enough to be carried by the air current continued their journey through the system and entered the stainless steel elutriation filter. Finally, the particles able to penetrate this barrier $\left(\mathrm{PM}_{10}\right)$ were collected on $47 \mathrm{~mm}$ filters made of quartz fiber (in Bogotá) and glass fiber (in Manizales). $\mathrm{PM}_{10}$ losses by sedimentation in the deposition chamber have been shown to be negligible (on average only $0.6 \%$ and $0.1 \%$ (in volume) of samples sieved at $250 \mu \mathrm{m}$ and $63 \mu \mathrm{m}$, respectively) [35]. The surroundings to the sampling point were observed for safety, traffic characteristics, road condition, and land-use types $[23,36]$.

Filters were baked at $500{ }^{\circ} \mathrm{C}$ for $12 \mathrm{~h}$ before sampling and then conditioned for $48 \mathrm{~h}$ at a constant temperature and relative humidity $\left(20 \pm 2{ }^{\circ} \mathrm{C}\right.$ and RH $\left.50 \% \pm 5 \%\right)$. The weight of each filter was determined with a microbalance every $24 \mathrm{~h}$. The mass fraction of road dust per $\mathrm{m}^{2}\left(\mathrm{RD}_{10}\right)$ was calculated at each location by averaging the mass collected at the three sampling points.

\subsection{Chemical Analysis}

After sampling, filters were kept refrigerated in the laboratory in a sealed bag protected from light until analysis. The road dust mass fraction per $\mathrm{m}^{2}\left(\mathrm{RD}_{10}\right.$ load) at each site was calculated by difference in filter weights before and after sample collection, and averaging the mass collected after weighing three times $\left(\mathrm{mg} / \mathrm{m}^{2}\right)$. After the sample weights were established, the filters were sent for destructive analysis at the "Laboratorio de Análisis Ambiental de la Universidad Nacional de Costa Rica" (Heredia, Costa Rica). Each filter was divided into small parts for the analysis of ions $\left(3.5 \mathrm{~cm}^{2}\right.$ approximately for ion chromatography, IC), minerals, and trace elements $\left(6.25 \mathrm{~cm}^{2}\right.$ approximately for inductively coupled plasma mass spectrometry, ICP-MS).

For mineral and trace elements, a portion of the impacted filter was acid-digested using $10 \mathrm{~mL}$ of a mixture of $\mathrm{HNO}_{3}(5.55 \% \mathrm{v} / \mathrm{v})$ and $\mathrm{HCl}(16.75 \% \mathrm{v} / \mathrm{v})$ with deionized water. Microwave heating for $15 \mathrm{~min}$ was used by temperature ramps that reached $200{ }^{\circ} \mathrm{C}$. After achieving $200^{\circ} \mathrm{C}$, the temperature was maintained for another $15 \mathrm{~min}$. Then, this solution was filtered through a quantitative filter and diluted with deionized water in a $25 \mathrm{~mL}$ volumetric flask. A $15 \mathrm{~mL}$ aliquot was transferred to the sampler tubes of the spectroscope. The digested samples were injected to the ICP-MS by a peristaltic pump to the nebulizer system, where it was transformed into an aerosol due to the action of argon gas. The ions that originated in the argon plasma were injected into the mass spectrometer, mass/charge ratio was used for the identification.

Another portion of the filter was leached into $30 \mathrm{~mL}$ of deionized water in an ultrasonic bath for $45 \mathrm{~min}$ for the extraction of water-soluble ions. The residual liquid was then filtered through a membrane filter and diluted with deionized water in a $50 \mathrm{~mL}$ volumetric flask. A portion of the liquid was taken then for further analysis by IC. Sulphate, nitrate, and chloride ions were analyzed [37]. The blanks were submitted to the same chain of custody and treatment as the samples. The Supplementary Materials Table S1 shows the calculations made for the determination of charges for each chemical species. 


\subsection{Enrichment Factors}

Enrichment factors (EFs) were calculated for the fraction of road dust using Equation (1). EFs have generally been used to determine the degree of enrichment from anthropogenic sources in road dust [24].

$$
\mathrm{EF}_{\text {Element }}=\frac{\left(\text { Element } \mathrm{RD}_{10} / \text { Reference } \mathrm{RD}_{10}\right)}{(\text { Element Crust } / \text { Reference Crust })}
$$

where element is the concentration of the element under consideration and reference is the concentration of the chosen referenced element. Subscripts indicate to which source the concentration refers, sample $\left(\mathrm{RD}_{10}\right)$ or the earth's crust (Crust). EF values were calculated based on the upper continental crust composition (see Supplementary Materials Table S2) using aluminum as the reference element [38]. Aluminum was selected because it is one of the most abundant elements in the earth's crust, and it has been the most used normalizing element in the geochemical literature $[38,39]$. The enrichment values of elements from anthropogenic sources are classified according to the following ranges: minimal $(\mathrm{EF}=1-2)$, moderate $(E F=2-5)$, significant $(E F=5-20)$, very high $(E F=20-40)$, and extremely high $(\mathrm{EF}>40)[40]$.

\subsection{Principal Component Analysis (PCA)}

A PCA was carried out to explore qualitative contributions to the chemical composition of $\mathrm{RD}_{10}$ from different factors associated with sources such as brake wear, tire wear, fugitive dust, industrial emissions, and natural emissions, among others. The factors identified by PCA can be associated with emissions sources, but they do not represent the actual sources. The application of a more refined receptor model was not possible due to the lower number of samples. PCA was performed for the dataset recorded in Bogotá and Manizales, and a varimax rotation (with Kaiser normalization) was applied to facilitate the interpretation of the results. In general, this method of rotation maximizes the sum of the variance of the squared loadings, where 'loadings' means correlations between variables and factors. This usually results in high factor loadings for a smaller number of variables and low factor loadings for the rest. The remaining components all have eigenvalues of more than one. In simple terms, the result is that a small number of important variables are highlighted, which makes it easier to interpret the principal component analysis [41].

\section{Results and Discussion}

\section{1. $R D_{10}$ Levels}

The $\mathrm{RD}_{10}$ loadings observed in Bogotá (average $11.8 \mathrm{mg} / \mathrm{m}^{2}$, interquartile range between $6.0-16.1 \mathrm{mg} / \mathrm{m}^{2}$ ) and Manizales (average $5.7 \mathrm{mg} / \mathrm{m}^{2}$, interquartile range between 2.4-7.2 mg $/ \mathrm{m}^{2}$ ) were comparable to those reported for European cities such as Barcelona $\left(3.0-80.0 \mathrm{mg} / \mathrm{m}^{2}\right)$, Birmingham $\left(3.8-42.7 \mathrm{mg} / \mathrm{m}^{2}\right)$, the Andalusia region $\left(2.0-22.0 \mathrm{mg} / \mathrm{m}^{2}\right)$, and Turin $\left(0.8-42.7 \mathrm{mg} / \mathrm{m}^{2}\right)$, but they were higher than Girona $\left(1.3-7.1 \mathrm{mg} / \mathrm{m}^{2}\right)$, Porto $\left(0.1-0.9 \mathrm{mg} / \mathrm{m}^{2}\right)$, Paris $\left(0.7-2.2 \mathrm{mg} / \mathrm{m}^{2}\right)$, and Zürich $\left(0.2-1.3 \mathrm{mg} / \mathrm{m}^{2}\right)$. However, $\mathrm{RD}_{10}$ values in Bogotá and Manizales were lower than New Delhi in India $\left(44.0-106.0 \mathrm{mg} / \mathrm{m}^{2}\right)$ (Table 2).

$\mathrm{RD}_{10}$ loadings were higher and more variable in Bogotá than in Manizales (Figure 2, panel a). The three highest loadings in Bogotá $\left(45.8,23.1\right.$, and $21.1 \mathrm{mg} / \mathrm{m}^{2}$ at ID points 8 , 15 , and 16, respectively, Figure 3) were sites located close to demolition/construction works in the southwest of the city, the same area where ambient $\mathrm{PM}_{10}$ is frequently exceeded. In Manizales, the three highest loadings $\left(26.7,11.7\right.$, and $8.5 \mathrm{mg} / \mathrm{m}^{2}$ at ID points 1,2 , and 4 , respectively, Figure 4) were found in sites with industrial activity and poor road pavement conditions in the eastern areas. 
Table 2. Comparison of road dust loads from this study and others reported for different regions.

\begin{tabular}{|c|c|c|c|c|}
\hline Source & City & Site Features & $\mathrm{RD}_{10}\left(\mathrm{mg} / \mathrm{m}^{2}\right)$ & Season \\
\hline \multirow{4}{*}{ [35] } & \multirow{4}{*}{ Barcelona, Spain } & City Center-Urban Zone & $3.0-23.0$ & \multirow{4}{*}{ Summer } \\
\hline & & Ring roads with heavy traffic & $24.0-80.0$ & \\
\hline & & Urban tunnel & 13.0 & \\
\hline & & Demolition/construction area & $2.5-471.0$ & \\
\hline \multirow{4}{*}{ [8] } & Barcelona, Spain & Urban Zone & $3.7-23.1$ & \multirow{4}{*}{$\begin{array}{l}\text { Spring/ } \\
\text { Summer }\end{array}$} \\
\hline & \multirow{2}{*}{ Girona, Spain } & Urban Zone & $1.3-7.1$ & \\
\hline & & Demolition/construction area & 48.7 & \\
\hline & Zürich, Switzerland & Urban Zone & $0.2-1.3$ & \\
\hline$[42]$ & Andalucía, Spain & Urban Zone & $2.0-22.0$ & Summer \\
\hline \multirow{3}{*}[21]{} & \multirow{2}{*}{ Birmingham, UK } & High traffic highway & $3.8-21.8$ & \multirow{3}{*}{ Dry season } \\
\hline & & High traffic tunnel & $3.0-36.1$ & \\
\hline & New Delhi, India & High traffic highway & $44.0-106.0$ & \\
\hline \multirow{2}{*}{ [17] } & \multirow{2}{*}{ Paris, France } & Urban Zone & $0.7-2.2$ & \multirow{2}{*}{ Spring } \\
\hline & & Cobblestone pavement & 10.3 & \\
\hline \multirow{2}{*}{ [7] } & \multirow{2}{*}{ Porto, Portugal } & Paved road & $0.1-0.9$ & \multirow{2}{*}{ Summer } \\
\hline & & Cobblestone pavement & 50.0 & \\
\hline \multirow{4}{*}{ [43] } & Barcelona, Spain & Urban Zone & $1.1-3.4$ & Summer \\
\hline & & Urban Zone & $0.8-8.8$ & \multirow{3}{*}{ Summer and winter } \\
\hline & Turin, Italy & Roads in proximity to unpaved parks & 12.3 & \\
\hline & & Demolition/construction area & $11.5-42.7$ & \\
\hline \multirow{2}{*}{ Current study } & Bogotá, Colombia & Urban Zone & $1.8-45.7$ & \multirow{2}{*}{ Dry season } \\
\hline & Manizales, Colombia & Urban Zone & $0.8-26.7$ & \\
\hline
\end{tabular}

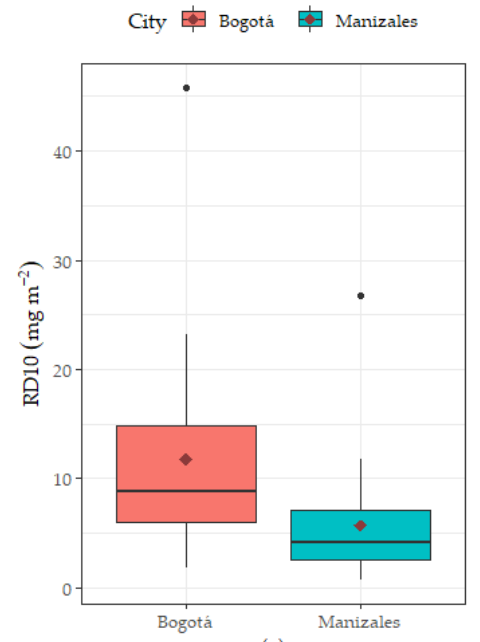

(a)

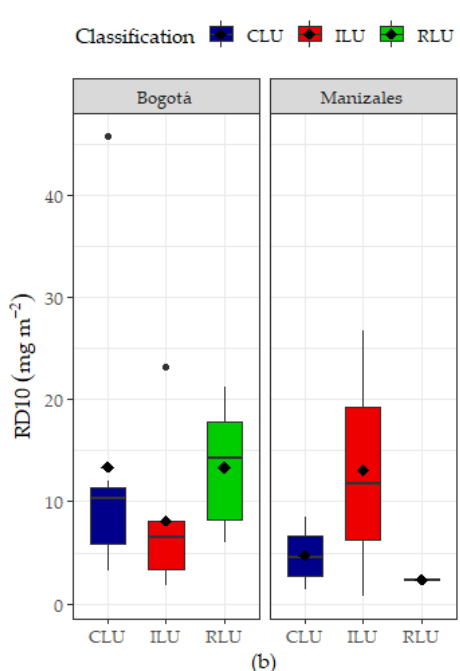

Figure 2. Road dust loads boxplots (a) for Bogotá and Manizales and (b) grouped by land use for Bogotá and Manizales-CLU: commercial land use; ILU—industrial land use; RLU—residential land use. 


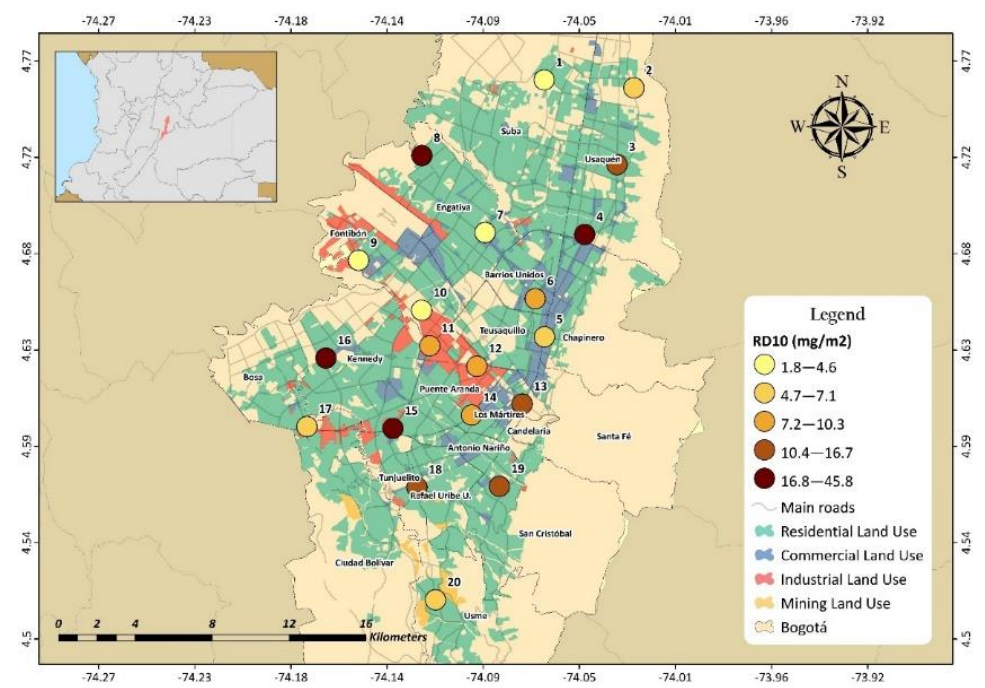

Figure 3. Spatial distribution of road dust loads in Bogotá.

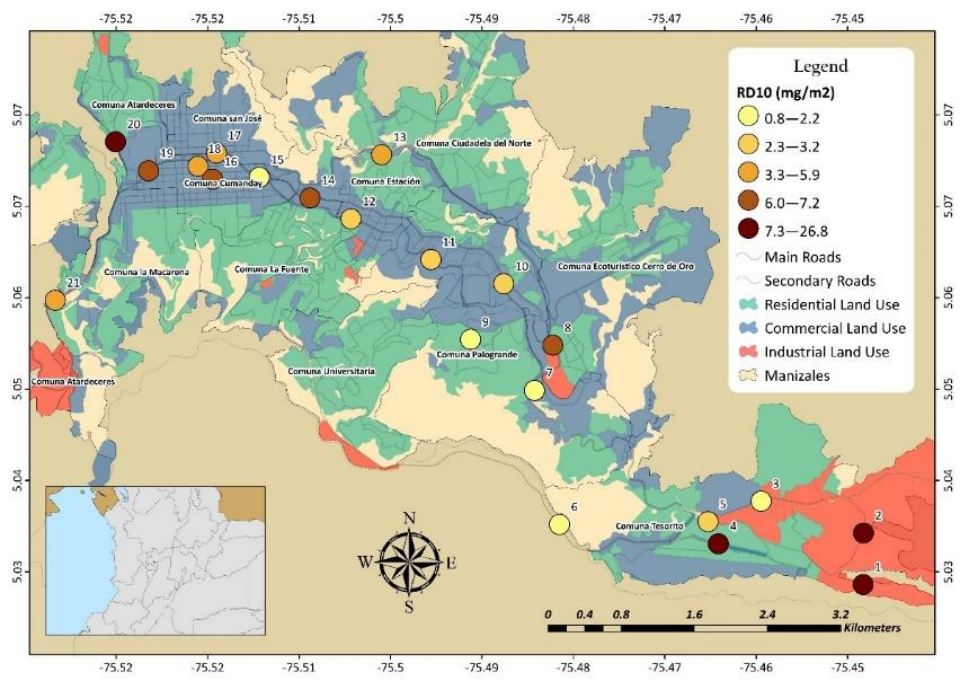

Figure 4. Spatial distribution of road dust loads in Manizales.

Differences in $\mathrm{RD}_{10}$ levels in Bogotá and Manizales can be partially explained by urban planning. As it can be identified from Figures 3 and 4, Manizales displays a central axis of commercial activity surrounded by residential areas. The industrial sector is located mainly towards the southeastern areas of the city. In contrast, industrial facilities in Bogotá are spread in the central and southwestern areas of the city, in conjunction with residential and commercial areas. These differences in land-use features determine, in part, levels of $\mathrm{RD}_{10}$. The higher values in Bogotá were not only attributed to industrial zones but to areas with a mix of industries, heavy traffic, commercial facilities, and poor road condition, in addition to building and road construction.

Dust loadings in residential areas in Bogotá were larger than those observed in commercial or industrial zones. In contrast, $\mathrm{RD}_{10}$ levels were the highest under industrial land use in Manizales. Residential areas showed the lowest values (Figure 2, panel b). As it was described, urban development in Bogotá has resulted in zones where industrial and commercial sectors coexist with residential use. One of such zones is the southwest of the city (Figure 3). This area has heavy traffic, a higher fraction of unpaved roads and poor pavement conditions, quarrying/mining activity, and the presence of eroded soils. In Manizales, areas categorized under industrial land use also show heavy vehicular traffic and poor pavement quality, which explains the highest $\mathrm{RD}_{10}$ values. In residential areas with predominance of light vehicle circulation, dust loadings were the lowest (average 
$2.37 \mathrm{mg} / \mathrm{m}^{2}$ ). Lastly, in areas with mixed land use (institutional, commercial, and services), the average $\mathrm{RD}_{10}$ was $4.58 \mathrm{mg} / \mathrm{m}^{2}$ (Figure 2, panel $\mathrm{b}$ and Figure 4 ).

\subsection{Chemical Profile}

Mineral elements such as $\mathrm{Al}, \mathrm{Ca}, \mathrm{Fe}, \mathrm{K}, \mathrm{Mg}, \mathrm{Mn}, \mathrm{Na}$, and Ti represented $9.0 \%$ the total $\mathrm{RD}_{10}$ mass in Bogotá, with an average load of $1020 \mu \mathrm{g} / \mathrm{m}^{2}$; meanwhile, mineral contribution in Manizales comprised $37.8 \%$ of the $\mathrm{RD}_{10}$ mass $\left(1952 \mu \mathrm{g} / \mathrm{m}^{2}\right)$. Mineral compounds are abundant in the thoracic fraction of road dust [25] and can influence the mass percentage distribution. The mineral fraction was significantly larger in Manizales than Bogotá (Figure 5a). However, other studies have found greater contributions of the mineral component in $\mathrm{RD}_{10}$ in Colombia, $62 \% \pm 26 \%$ in Bogotá and $23 \% \pm 18 \%$ in Barranquilla $[24,25]$. In cities such as Barcelona, New Delhi, and Fushun, the contribution was found to be in the range of $25-35 \%[21,35,44]$. The contribution percentages of the main elements to total mass might be underestimated due to the fact that elements such as metalloids ( $\mathrm{Si})$, oxides $\left(\mathrm{Al}_{2} \mathrm{O}_{3}, \mathrm{CO}_{3}{ }^{-2}, \mathrm{SiO}_{2}\right)$, and organic matter were not analyzed.

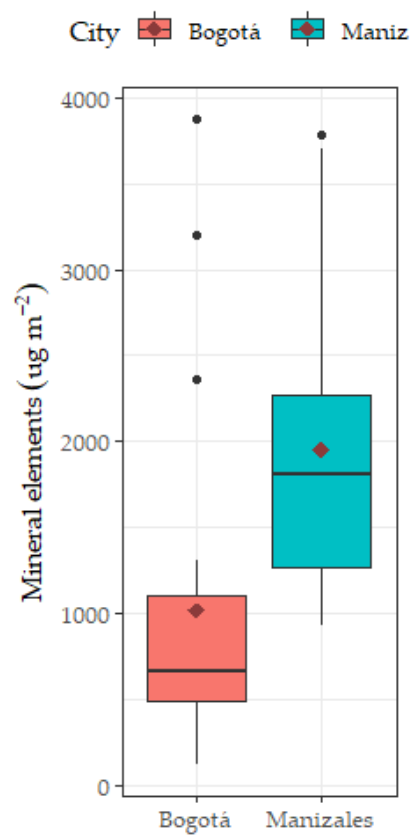

(a)

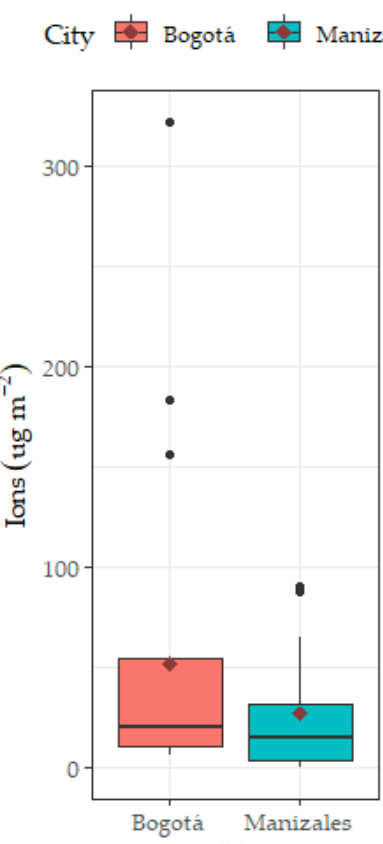

(b)

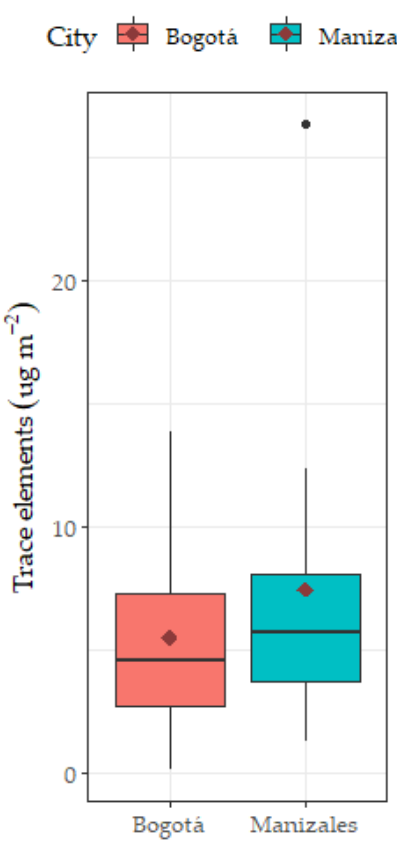

(c)

Figure 5. Total load of (a) mineral elements, (b) ions, and (c) trace elements determined for Bogotá and Manizales.

The fraction of water-soluble ions $\left(\mathrm{SO}_{4}{ }^{-2}, \mathrm{NO}_{3}{ }^{-}\right.$and $\left.\mathrm{Cl}^{-}\right)$represented less than $1.0 \%$ of the total mass in Bogotá (average load $51.52 \mu \mathrm{g} / \mathrm{m}^{2}$ ) and Manizales (average load $26.64 \mu \mathrm{g} / \mathrm{m}^{2}$ ) (Figure $5 \mathrm{~b}$ ). Previously, a larger ions contribution of $3.8 \% \pm 1.1 \%$ was observed in Bogotá [24], similar to Barcelona, Spain (2.4\%) [35], but higher than Fushun, China (0.5\%) [44].

Trace metals (Ag, As, Be, Cd, Co, Cr, $\mathrm{Cu}, \mathrm{Hg}$, Mo, $\mathrm{Ni}, \mathrm{Pb}, \mathrm{Sb}, \mathrm{Se}$, and $\mathrm{V}$ ), with an average load of $5.54 \mu \mathrm{g} / \mathrm{m}^{2}$ and $7.48 \mu \mathrm{g} / \mathrm{m}^{2}$, represented $0.05 \%$ and $0.13 \%$ of the total mass captured from $\mathrm{RD}_{10}$ in Bogotá and Manizales, respectively (Figure 5c). In Bogotá, Barcelona, and Fushun, trace metals represented $0.5 \%, 0.36 \%$, and $0.66 \%$, respectively $[24,35,44]$. The Supplementary Materials Table S3 shows results of each of the chemical species analyzed.

In Bogotá, $89.4 \%$ of the mineral load was composed of four crustal metals: $\mathrm{Al}(33.6 \%)$, $\mathrm{Ca}(28.0 \%), \mathrm{Fe}(19.5 \%)$, and $\mathrm{Na}(8.3 \%)$. The origin of these metals can be associated to: (i) poor road condition and unpaved roads; (ii) low or null vegetation cover [45]; (iii) road and building construction [17,35]; and (iv) quarries and mining areas [46] (Figure 6a). In Manizales, five crustal elements comprised $92.8 \%$ of the mineral components: $\mathrm{Na}(34.3 \%)$, 
$\mathrm{Al}(20.5 \%), \mathrm{K}(14.1 \%), \mathrm{Ca}(14.0 \%)$, and $\mathrm{Fe}(9.9 \%)$. The sources of these elements are mainly related to the resuspension of fugitive dust (earth's crust material of volcanic geological formation, Figure 6b). In effect, previous studies in the Manizales area have highlighted the presence of high contents of $\mathrm{Si}, \mathrm{Al}$, and $\mathrm{Fe}$, as well as compounds such as plagioclase feldspar (Ca-Na) and volcanic glass, among others, in the chemical composition of the soil derived from volcanic ash [47]. Likewise, Trejos et al. [36] found traces of volcanic ash, such as hydrated complexes of $\mathrm{Al}, \mathrm{Si}$, and $\mathrm{K}$; heavy metals like $\mathrm{As}, \mathrm{Hg}, \mathrm{Cd}$, and $\mathrm{Pb}$; and specific compounds, such as ammonia salt and plagioclase feldspar (Ca-Na), in soil dust from Manizales. This volcanic influence may explain the higher loads of $\mathrm{Al}, \mathrm{K}$, and $\mathrm{Na}$ in Manizales in comparison to Bogotá (Figure 7).
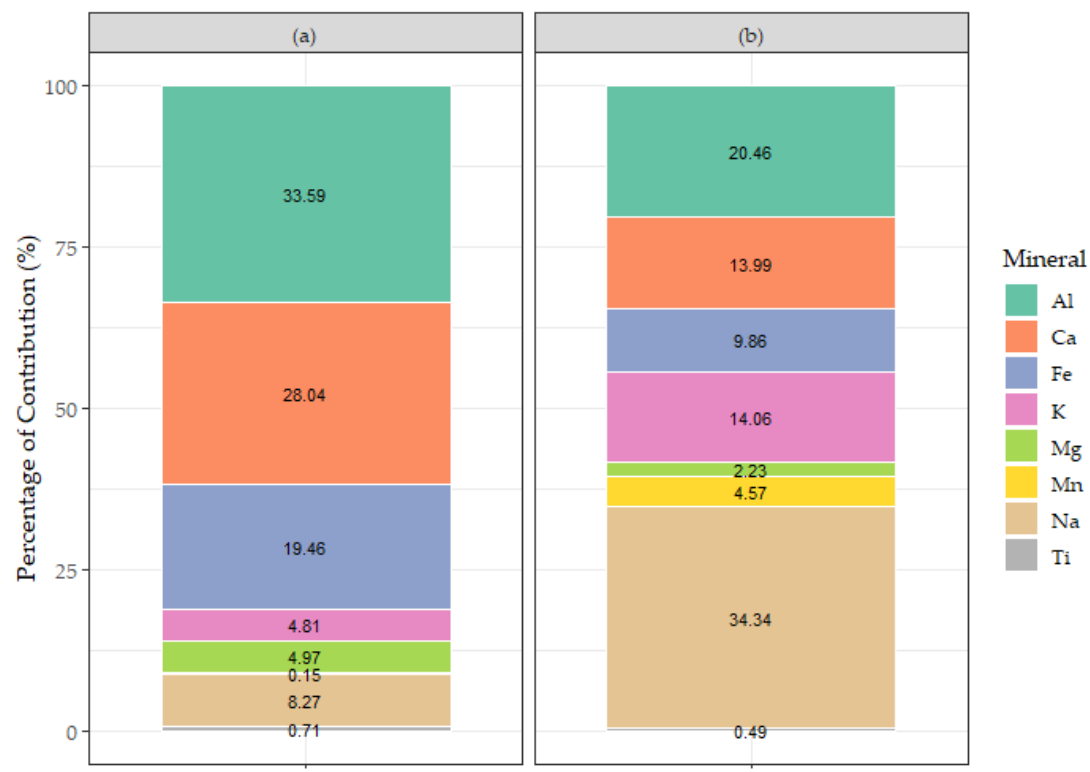

Figure 6. Average composition of main elements for: (a) Bogotá and (b) Manizales.

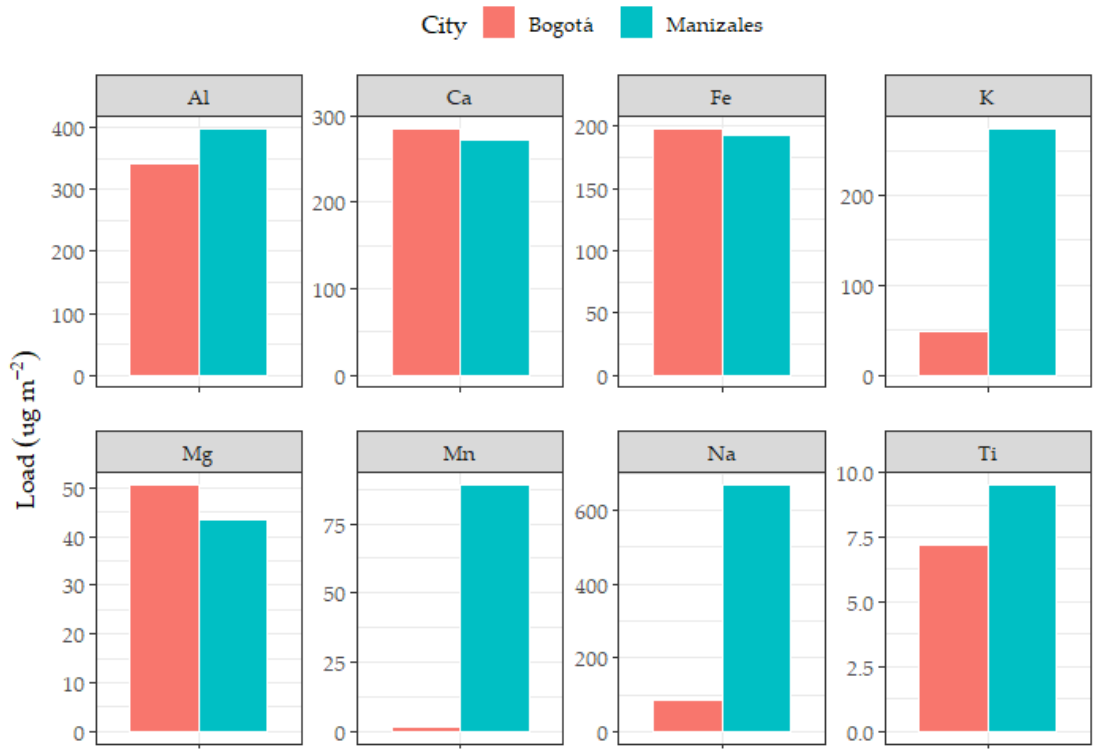

Figure 7. Individual load of main elements obtained in Bogotá and Manizales.

Despite their low fraction in mass, sulphate and nitrate were the most abundant ions in soil dust in Bogotá and Manizales (Figure 8). The precursors of these compounds are associated with pavement wear [46], vehicle exhaust emissions, and formation of 
secondary inorganic aerosols [48,49]. $\mathrm{Cl}^{-}$showed a contribution of $7.4 \%$ in Bogotá and $20.9 \%$ in Manizales. The latter is mainly associated with the composition of soils derived from volcanic ash, where $\mathrm{Cl}^{-}, \mathrm{HCO}_{3}{ }^{-}$, and $\mathrm{SO}_{4}{ }^{-2}$ predominate among soluble anions [47] and the deposition of secondary particles formed from precursor gases, such as $\mathrm{HCl}$ [24], emitted from the Nevado del Ruiz volcano.

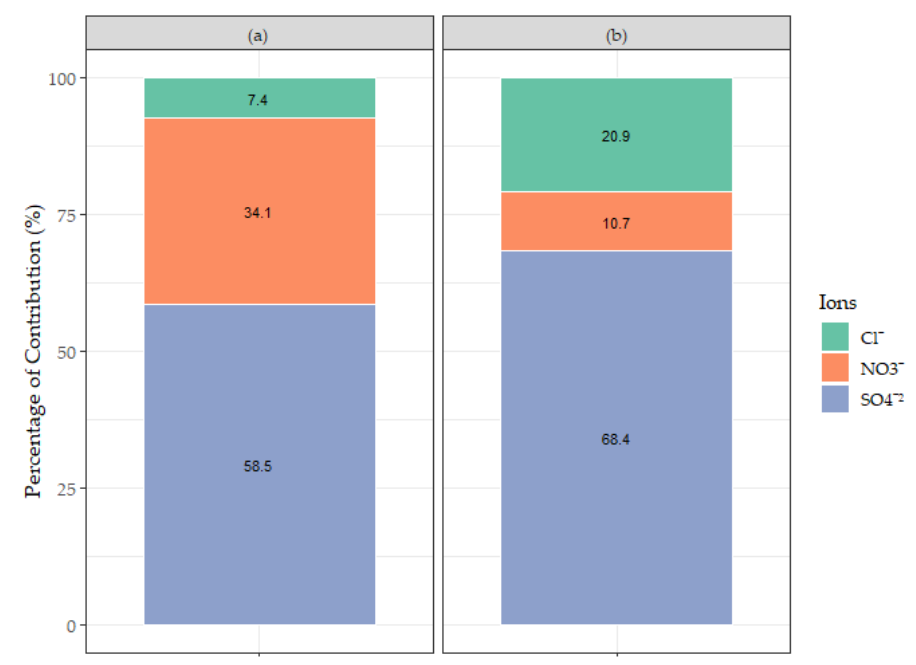

Figure 8. Water-soluble ion distribution for (a) Bogotá and (b) Manizales.

Trace elements, such as $\mathrm{Cu}, \mathrm{Pb}, \mathrm{Cr}, \mathrm{Ni}, \mathrm{V}$, and $\mathrm{Sb}$, comprised $96.0 \%$ of the mass attributed to this component in Bogotá (Figure 9). These metals are commonly associated with vehicle exhaust emissions, especially the use of antioxidants, additives, and lubricants $(\mathrm{Cu}$ and $\mathrm{Pb})$, mechanical abrasion $(\mathrm{Cu})$, and tire/brake wear $(\mathrm{Cu}, \mathrm{Pb}, \mathrm{Ni}, \mathrm{V}$, and $\mathrm{Sb})[10,17,19]$. In the case of Manizales, the contents of $\mathrm{Cu}$ and $\mathrm{Pb}$ were lower, but there was a significant mass of Mo (11\%) in comparison to Bogotá (Figure 9). Molybdenum is mainly associated with emissions from the steel industry [50,51] and brake wear [42]. Both situations are relevant in Manizales, with a relatively large industrial sector and a complex topography that requires a strong use of brakes in steep streets with slopes that could be greater than $22 \%$ [52].

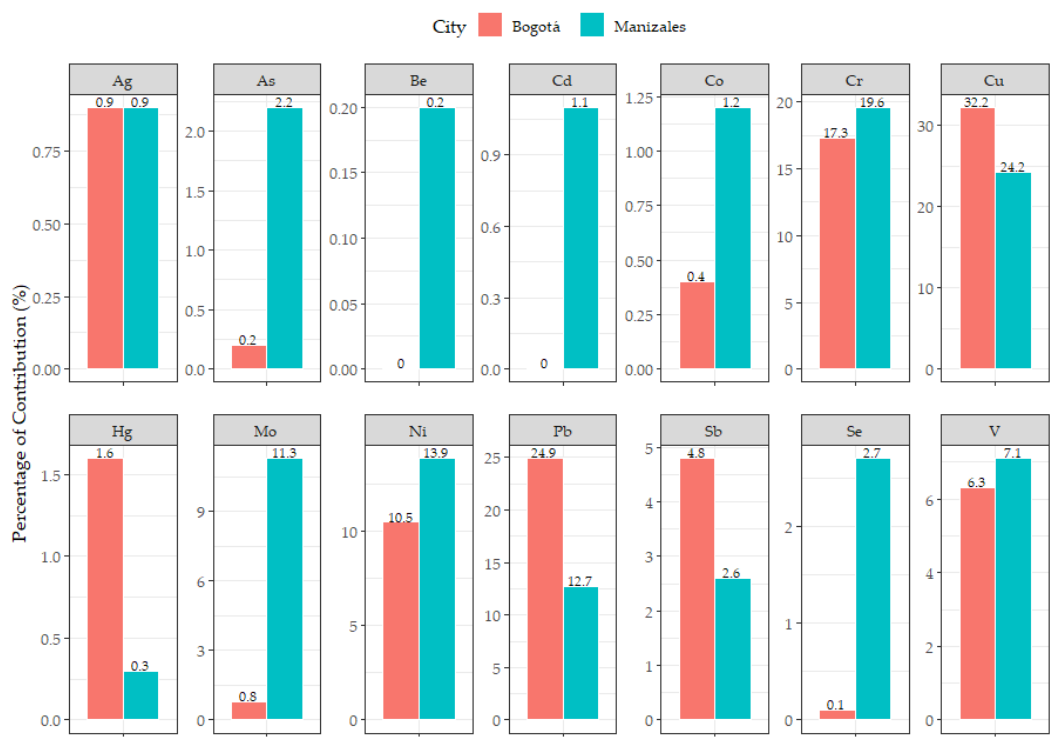

Figure 9. Average composition of traces for Bogotá and Manizales. 


\subsection{Source Exploration by EFs}

Enrichment factors were estimated with the aim to explore the anthropogenic influence of some crustal elements (Ca, Fe, K, and $\mathrm{Mn}$ ) and trace metals (As, $\mathrm{Co}, \mathrm{Cr}, \mathrm{Cu}, \mathrm{Mo}, \mathrm{Ni}, \mathrm{Pb}$, $\mathrm{Sb}, \mathrm{Se}$, and V). Aluminum was used as a reference element, given its abundance in the upper continental crust. In Bogotá, EFs showed extremely high values $(\mathrm{EF}>40)$ for Mo and $\mathrm{Sb}$; very high $(20<\mathrm{EF}<40)$ for $\mathrm{Cu}$ and $\mathrm{Pb}$; high $(5<\mathrm{EF}<20)$ for $\mathrm{Ni}$, Se, and $\mathrm{Cr}$; and moderate $(\mathrm{EF}<5)$ for $\mathrm{Ca}, \mathrm{Fe}, \mathrm{V}$, and As. In Manizales, EFs were extremely high (EF $>40)$ for $\mathrm{Mo}$, Se, Sb, and Mn; very high $(20<\mathrm{EF}<40)$ for $\mathrm{Cu}$ and As; high $(5<\mathrm{EF}<20)$ for $\mathrm{Ni}$, $\mathrm{Cr}$, and $\mathrm{Pb}$; and moderate $(1<\mathrm{EF}<5)$ for $\mathrm{K}, \mathrm{Ca}, \mathrm{V}, \mathrm{Co}$, and Fe (Figure 10).

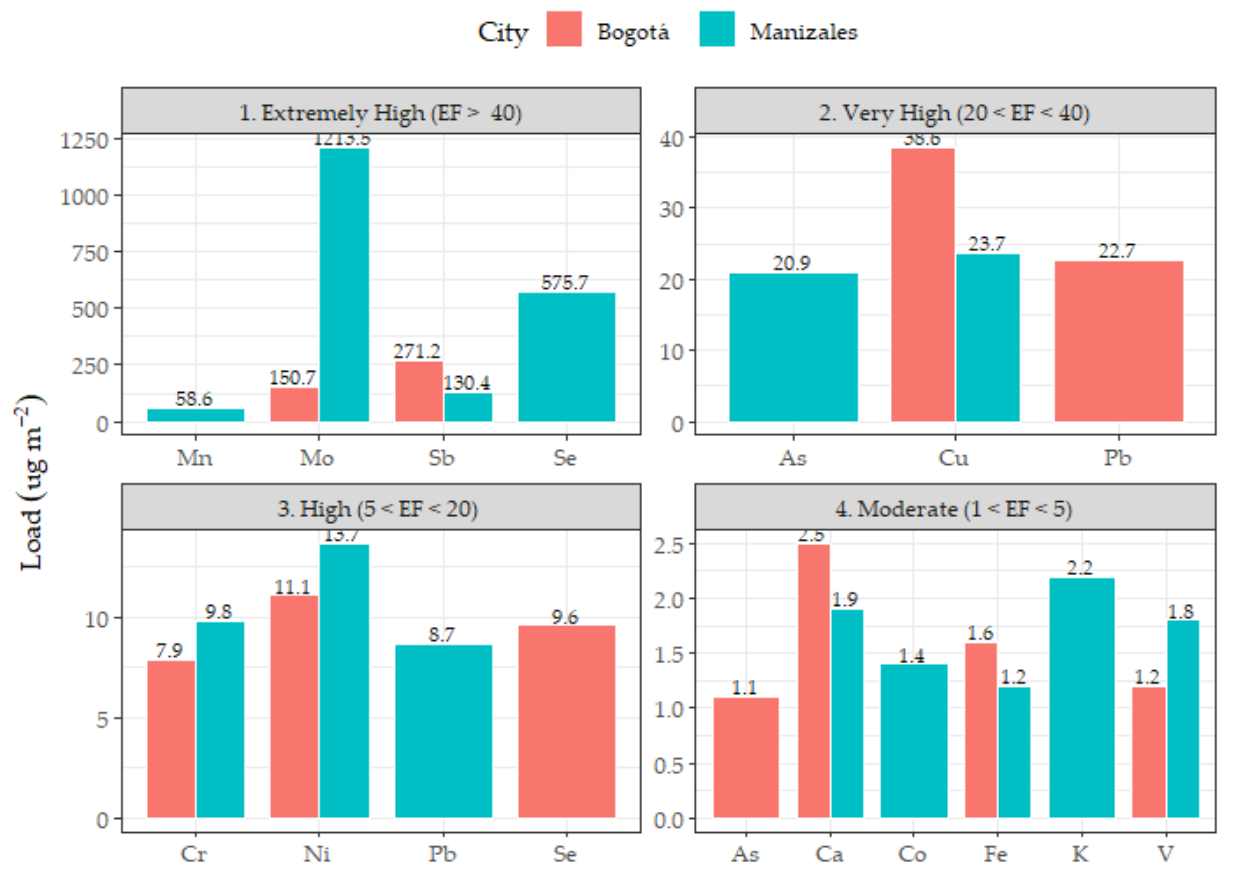

Figure 10. Enrichment factors in Bogotá and Manizales.

The presence of $\mathrm{Sb}, \mathrm{Ba}, \mathrm{Cu}, \mathrm{Fe}$, and $\mathrm{Mn}$ in road dust samples can be associated with brake wear [53]. Antimony was, in particular, the element that recorded the highest levels of enrichment in Bogotá ( $E F=271)$, and it was among the highest in Manizales ( $E F=130)$. Despite the relatively low number of vehicles $(169,142)$, the complex topography and steep roads in Manizales imply the heavy use of brakes [36]. In Bogotá, the greater vehicular volume (approximately 2 million vehicles) and traffic congestion explain the frequent use of brakes.

The EF of Sb was higher than those reported in high-traffic cities such as Moscow, Russia (EF $=44)[19]$ and those registered in some roads in Barranquilla (EF close to 100) [25], but it was similar, and even lower, than those observed in high traffic roads in Viana do Castelo, Portugal $(100<\mathrm{EF}<1000)$ [13]. Ramírez et al. [24] reported a Sb enrichment factor close to 140 for commercial-use areas in Bogotá, which was lower than those found in this study. In accordance with the chemical composition of the brake pads, a $\mathrm{Cu} / \mathrm{Sb}$ ratio $>7$ has been proposed for brake wear emissions in road dust [21,35]. An average $\mathrm{Cu} / \mathrm{Sb}$ ratio of 7.6 for Bogotá and 9.2 for Manizales was observed, confirming the relevant contribution of brake wear to road dust.

Molybdenum registered an enrichment factor eight times higher in Manizales $(\mathrm{EF}=1213)$ than Bogotá $(\mathrm{EF}=151)$. The obtained $\mathrm{EF}$ values of $\mathrm{Mb}$ in cities such as Moscow $(\mathrm{EF}=7)[19]$ and Toronto $(\mathrm{EF}=0.9)[51]$ were much lower than the values observed in Colombia. Molybdenum has been associated with various industrial emissions, mainly those related to incinerators and with the mechanical/metallurgical industry [19]. Likewise, Mo is associated with brake pad abrasion [51]. A high correlation of Mo with Co (0.96), $\mathrm{Hg}$ 
(0.73), $\mathrm{Pb}(0.74)$, Se (0.61), and V (0.94) in Manizales suggests a common source of origin, related with the industrial activity in the city (see Supplementary Materials Figure S1). In addition, the high correlation of Mo with elements found in volcanic ash, such as $\mathrm{Cd}(1.0)$, $\mathrm{Pb}(0.74), \mathrm{V}(0.94)$, and $\mathrm{Fe}(0.84)$, suggests a potential contribution of volcanic emissions to the observed enrichment levels [36].

Selenium showed the second-highest EF value in Manizales $(E F=576)$, a level that was higher than those reported in Bogotá [24] and Viana do Castelo [13]. The enrichment of Se is commonly associated with anthropogenic emissions, including combustion (coal, oil, wood, and biomass), non-ferrous melting, manufacturing, and use of agricultural products. The correlations of Se with As (0.63), Cd (0.62), Mo (0.61), and V (0.63) (Figure S1) suggest a contribution from industrial activity and possible influence of the Nevado del Ruiz volcano $[24,36,54]$.

$\mathrm{Cu}, \mathrm{Pb}, \mathrm{Ni}$, and $\mathrm{Cr}$ presented high and very high EFs $(5<\mathrm{EF}<40)$, widely associated with mechanical abrasion and tire/brake wear $[19,24,51]$. In Manizales, As also showed a high EF, possibly associated with coal combustion [55] and volcanic emissions (moderate correlation of As with $\mathrm{SO}_{4}{ }^{-2}(0.62)$ and $\left.\mathrm{Se}(0.63)\right)$.

\subsection{Factors Associated to Sources in PCA Analysis}

In the PCA analysis, $92.2 \%$ of the total variance could be explained by five factors in Bogotá and six factors in Manizales (Table 3). Factors that explain at least $10.0 \%$ of the data variability were considered. In Bogotá, PC1 explained $42.3 \%$ of the variance and showed high correlations with elements associated with dust resuspension, pavement wear, road traffic, and the use of antioxidants, additives, and vehicle lubricants $(\mathrm{V}, \mathrm{Al}, \mathrm{Fe}, \mathrm{Ti}, \mathrm{As}$, $\mathrm{K}, \mathrm{Pb}, \mathrm{Co}, \mathrm{Mn}, \mathrm{Ca}$, and $\mathrm{Cr}$ ) [10,17]. PC2, explaining $25.9 \%$ of the variance, showed high correlations with $\mathrm{Se}, \mathrm{Na}, \mathrm{NO}_{3}$, and $\mathrm{Mg}$ and a moderate relation with $\mathrm{SO}_{4}$ and $\mathrm{Ca}$. PC2 is associated with construction/demolition activities [35,46]. Lastly, PC3 (16.7\% variance explained) is influenced by non-exhaust trace elements, such as $\mathrm{Sb}, \mathrm{Cu}, \mathrm{Mo}$, and $\mathrm{Ni}$ [19].

In Manizales, the first component (PC1) explained $37.8 \%$ of the total variance and had high correlations with $\mathrm{Co}, \mathrm{V}, \mathrm{Mo}, \mathrm{Cd}, \mathrm{Fe}, \mathrm{Ca}, \mathrm{Pb}, \mathrm{Mg}$, and Ti, suggesting an influence of tire and brake wear, as well as combustion processes [42,50,51]. PC2, a component that explained $18.7 \%$ of the total variance, was mainly influenced by $\mathrm{SO}_{4}, \mathrm{As}$, and $\mathrm{K}$ with a lower influence of $\mathrm{Sb}, \mathrm{Mg}, \mathrm{Ti}, \mathrm{Al}$, and $\mathrm{Cr}$. This factor may be associated with the road abrasion and volcanic ash emissions [24,36]. Lastly, PC3 (10.1\% of the variance) was correlated with $\mathrm{Na}, \mathrm{K}$, and $\mathrm{Al}$, suggesting a contribution related to the resuspension of fugitive dust and volcanic ash $[36,47]$.

Table 3. Rotated component of PCA for road dust in Bogotá $(n=20)$ and Manizales $(n=14)$. Only significant values (>0.32) are presented. Highest values (>0.7) are shown in red.

\begin{tabular}{|c|c|c|c|c|c|c|c|c|c|c|c|}
\hline \multicolumn{5}{|c|}{ Rotated Component Matrix ${ }^{\mathrm{a}}-\mathrm{RD}_{10}$ Bogotá } & \multicolumn{7}{|c|}{ Rotated Component Matrix ${ }^{b}-R_{10}$ Manizales } \\
\hline Element & PC1 & PC2 & PC3 & PC4 & Element & PC1 & PC2 & PC3 & PC4 & PC5 & PC6 \\
\hline $\mathbf{V}$ & 0.97 & & & & Co & 0.98 & & & & & \\
\hline Al & 0.96 & & & & $\mathbf{V}$ & 0.97 & & & & & \\
\hline $\mathbf{F e}$ & 0.96 & & & & Mo & 0.96 & & & & & \\
\hline Ti & 0.92 & & & & Cd & 0.96 & & & & & \\
\hline As & 0.85 & 0.35 & & & Fe & 0.91 & & & & & \\
\hline $\mathbf{K}$ & 0.82 & 0.52 & & & $\mathbf{C a}$ & 0.83 & & & & & \\
\hline $\mathbf{P b}$ & 0.78 & & 0.4 & & $\mathbf{P b}$ & 0.79 & & & & 0.49 & \\
\hline Co & 0.78 & 0.47 & & & $\overline{M g}$ & 0.75 & 0.54 & & & & \\
\hline Mn & 0.77 & 0.57 & & & $\mathbf{T i}$ & 0.71 & 0.54 & & & & \\
\hline $\mathrm{Ca}$ & 0.75 & 0.61 & & & $\mathrm{SO}_{4}$ & & 0.90 & & & & \\
\hline $\mathrm{Cr}$ & 0.71 & 0.38 & 0.52 & & As & 0.35 & 0.79 & & & & \\
\hline Se & 0.34 & 0.90 & & & $\mathbf{K}$ & & 0.77 & 0.55 & & & \\
\hline $\mathrm{Na}$ & 0.33 & 0.88 & & & $\mathrm{Na}$ & 0.49 & & 0.72 & & 0.38 & \\
\hline
\end{tabular}


Table 3. Cont.

\begin{tabular}{|c|c|c|c|c|c|c|c|c|c|c|c|}
\hline \multicolumn{5}{|c|}{ Rotated Component Matrix ${ }^{\mathrm{a}}-\mathrm{RD}_{10}$ Bogotá } & \multicolumn{7}{|c|}{ Rotated Component Matrix ${ }^{b}-R_{10}$ Manizales } \\
\hline Element & PC1 & PC2 & PC3 & PC4 & Element & PC1 & PC2 & PC3 & PC4 & PC5 & PC6 \\
\hline $\mathrm{NO}_{3}$ & & 0.88 & & & $\mathrm{Ni}$ & & & & 0.86 & & \\
\hline Mg & 0.54 & 0.77 & & & Mn & & & & & 0.97 & \\
\hline $\mathrm{Sb}$ & & & 0.86 & & $\mathrm{NO}_{3}$ & & & & & & 0.90 \\
\hline $\mathrm{Cu}$ & 0.35 & 0.36 & 0.83 & & $\mathrm{Cu}$ & 0.43 & 0.39 & & 0.53 & & 0.52 \\
\hline Mo & & 0.45 & 0.80 & & $\mathrm{Sb}$ & & 0.61 & & & & 0.46 \\
\hline $\mathbf{N i}$ & & & 0.72 & 0.42 & Al & 0.58 & 0.52 & 0.5 & & & \\
\hline $\mathrm{Cl}$ & & & & 0.92 & Se & 0.56 & 0.37 & & 0.4 & -0.38 & \\
\hline $\mathrm{SO}_{4}$ & 0.49 & 0.63 & & 0.55 & $\mathrm{Cr}$ & & 0.52 & & -0.66 & & \\
\hline $\mathrm{Cd}$ & & & & & $\mathrm{Cl}$ & & & -0.84 & & & \\
\hline Eigenvalues & 8.9 & 5.4 & 3.5 & 1.5 & Eigenvalues & 8.3 & 4.1 & 2.2 & 2.1 & 1.9 & 1.7 \\
\hline $\begin{array}{l}\text { Variance } \\
(\%)\end{array}$ & 42.3 & 25.9 & 16.7 & 7.2 & $\begin{array}{c}\text { Variance } \\
(\%)\end{array}$ & 37.8 & 18.7 & 10.1 & 9.3 & 8.5 & 7.7 \\
\hline Cum. (\%) & 42.3 & 68.3 & 85.0 & 92.2 & Cum. (\%) & 37.8 & 56.5 & 66.6 & 76 & 84.5 & 92.2 \\
\hline
\end{tabular}

Extraction method: principal component analysis. Rotation method: varimax with Kaiser normalization. ${ }^{a}$ Rotation converged in 6 iterations. ${ }^{b}$ Rotation converged in 14 iterations.

\section{Conclusions}

Road dust loadings and chemical composition were investigated in two Andean cities with different sizes, urban planning, and emission sources. $\mathrm{RD}_{10}$ levels were larger in Bogotá (average of $11.8 \mathrm{mg} / \mathrm{m}^{2}$ ) than in Manizales (average of $5.7 \mathrm{mg} / \mathrm{m}^{2}$ ) due to a higher vehicular volume and a large mix of land use features. Residential areas in Manizales showed the lowest $\mathrm{RD}_{10}$ values (average of $2.4 \mathrm{mg} / \mathrm{m}^{2}$ ), whereas industrial zones contributed the largest dust loadings (average of $13.1 \mathrm{mg} / \mathrm{m}^{2}$ ). Residential areas mixed with industrial and commercial activity showed significant levels of road dust in Bogotá (average of $13.4 \mathrm{mg} / \mathrm{m}^{2}$ ). Construction and demolition activities were identified as relevant emitters of road dust (dust loadings between $45.8-21.1 \mathrm{mg} / \mathrm{m}^{2}$ ).

Crustal elements ( $\mathrm{Al}, \mathrm{Ca}, \mathrm{Fe}, \mathrm{K}$, and $\mathrm{Na}$ ) were the most abundant elements in road dust in both cities. The complex topography in Manizales and the closeness to the Nevado del Ruiz volcano explain the high levels of crustal and trace metals in road dust, especially $\mathrm{Mo}, \mathrm{Se}, \mathrm{Sb}$, and $\mathrm{Mn}$. The volcanic activity was also associated with $\mathrm{SO}_{4}{ }^{-2}$ and $\mathrm{Cl}^{-}$. In Bogotá, $\mathrm{Cu}, \mathrm{Pb}, \mathrm{Cr}, \mathrm{Ni}, \mathrm{V}, \mathrm{Sb}$, and Mo were associated with combustion and non-exhaust (brake, tire, and road wear) emissions. Finally, the study of the influential factors and chemical composition of road dust, as well as its spatial variability, is crucial for public agencies and research centers to identify the origins of PM, formulate mitigation measures, and identify possible adverse effects on the population.

Supplementary Materials: The following are available online at https://www.mdpi.com/article/10 .3390 /atmos12091109/s1, Figure S1: Correlation matrix of chemically analyzed elements for road dust in the cities of (a) Bogota and (b) Manizales, Table S1: Calculation methodology for determining loads in $\mathrm{RD}_{10}$, Table S2: Concentrations in upper continental crust, Table S3: Results of chemical species analyzed for each city.

Author Contributions: Conceptualization, B.H.A., O.R. and J.E.P.; data curation, S.V. and E.M.T.; formal analysis, S.V.; funding acquisition, B.H.A., O.R. and J.E.P.; investigation, S.V. and E.M.T.; methodology, S.V., E.M.T. and J.M.H.; project administration, B.H.A., O.R. and J.E.P.; resources, J.H.M., F.A. and L.F.O.S.; software, S.V. and E.M.T.; supervision, B.H.A., O.R., N.Y.R. and J.E.P.; validation, B.H.A., O.R., N.Y.R. and J.E.P.; visualization, S.V.; writing-original draft preparation, S.V. and E.M.T.; writing-review and editing, S.V., E.M.T., B.H.A., G.M.P., O.R., F.A., L.F.O.S., N.Y.R., C.Z. and J.E.P. All authors have read and agreed to the published version of the manuscript.

Funding: This research was funded by ECOPETROL under agreement 5224377; and CORPOCALDAS under agreement 107-2018.

Institutional Review Board Statement: Not applicable.

Informed Consent Statement: Not applicable. 
Data Availability Statement: The data presented in this study are available in the Supplementary Materials file.

Acknowledgments: The authors are grateful for the financial support provided by ECOPETROL and CORPOCALDAS. The authors' viewpoint does not necessarily reflect the official opinion of their institutions. We thank our students from CLIMA Research Group and Hydraulic Engineering and Environmental Research Group who developed the field campaigns. In addition, we would like to thank Universidad Nacional de Costa Rica, who supported the chemical analysis of the road dust samples. The author Guilherme M. Pereira acknowledges the Brazilian foundation Fundação de Amparo à Pesquisa do Estado de São Paulo (FAPESP, São Paulo Research Foundation; Grants nos. 2019/01316-8 and 2018/07848-9).

Conflicts of Interest: The authors declare no conflict of interest. In addition, the funders had no role in the design of the study; in the collection, analyses, or interpretation of data; in the writing of the manuscript; or in the decision to publish the results.

\section{References}

1. Pant, P.; Harrison, R.M. Estimation of the contribution of road traffic emissions to particulate matter concentrations from field measurements: A review. Atmos. Environ. 2013, 77, 78-97. [CrossRef]

2. Grigoratos, T.; Martini, G. Brake wear particle emissions: A review. Environ. Sci. Pollut. Res. 2014, 22, 2491-2504. [CrossRef]

3. Charron, A.; Polo-Rehn, L.; Besombes, J.-L.; Golly, B.; Buisson, C.; Chanut, H.; Marchand, N.; Guillaud, G.; Jaffrezo, J.-L. Identification and quantification of particulate tracers of exhaust and non-exhaust vehicle emissions. Atmos. Chem. Phys. Discuss. 2019, 19, 5187-5207. [CrossRef]

4. Harrison, R.M.; Jones, A.M.; Gietl, J.; Yin, J.; Green, D. Estimation of the Contributions of Brake Dust, Tire Wear, and Resuspension to Nonexhaust Traffic Particles Derived from Atmospheric Measurements. Environ. Sci. Technol. 2012, 46, 6523-6529. [CrossRef]

5. Kumar, P.; Pirjola, L.; Ketzel, M.; Harrison, R.M. Nanoparticle emissions from 11 non-vehicle exhaust sources-A review. Atmos. Environ. 2013, 67, 252-277. [CrossRef]

6. Thorpe, A.; Harrison, R.M. Sources and properties of non-exhaust particulate matter from road traffic: A review. Sci. Total Environ. 2008, 400, 270-282. [CrossRef] [PubMed]

7. Alves, C.; Evtyugina, M.; Vicente, A.; Vicente, E.; Nunes, T.; Silva, P.; Duarte, M.; Pio, C.; Amato, F.; Querol, X. Chemical profiling of PM10 from urban road dust. Sci. Total Environ. 2018, 634, 41-51. [CrossRef]

8. Amato, F.; Pandolfi, M.; Moreno, T.; Furger, M.; Pey, J.; Alastuey, A.; Bukowiecki, N.; Prevot, A.; Baltensperger, U.; Querol, X. Sources and variability of inhalable road dust particles in three European cities. Atmos. Environ. 2011, 45, 6777-6787. [CrossRef]

9. Guttikunda, S. Estimating Health Impacts of Urban Air Pollution. Public Health 2008, 16. Available online: https://urbanemissions. info/wp-content/uploads/docs/SIM-06-2008.pdf (accessed on 20 August 2021).

10. Hetem, I.G.; de Fatima Andrade, M. Characterization of Fine Particulate Matter Emitted from the Resuspension of Road and Pavement Dust in the Metropolitan Area of São Paulo, Brazil. Atmosphere 2016, 7, 31. [CrossRef]

11. Kupiainen, K.J.; Tervahattu, H.; Räisänen, M.; Mäkelä, T.; Aurela, M.; Hillamo, R. Size and Composition of Airborne Particles from Pavement Wear, Tires, and Traction Sanding. Environ. Sci. Technol. 2004, 39, 699-706. [CrossRef] [PubMed]

12. Khan, R.K.; Strand, M.A. Road dust and its effect on human health: A literature review. Epidemiol. Health 2018, 40, e2018013. [CrossRef] [PubMed]

13. Alves, C.A.; Vicente, E.; Vicente, A.M.; Rienda, I.C.; Tomé, M.; Querol, X.; Amato, F. Loadings, chemical patterns and risks of inhalable road dust particles in an Atlantic city in the north of Portugal. Sci. Total Environ. 2020, 737, 139596. [CrossRef]

14. Gulia, S.; Goyal, P.; Goyal, S.K.; Kumar, R. Re-suspension of road dust: Contribution, assessment and control through dust suppressants-A review. Int. J. Environ. Sci. Technol. 2018, 16, 1717-1728. [CrossRef]

15. Ostro, B.; Tobias, A.; Querol, X.; Alastuey, A.; Amato, F.; Pey, J.; Pérez, N.; Sunyer, J. The Effects of Particulate Matter Sources on Daily Mortality: A Case-Crossover Study of Barcelona, Spain. Environ. Health Perspect. 2011, 119, 1781-1787. [CrossRef]

16. Meister, K.; Johansson, C.; Forsberg, B. Estimated Short-Term Effects of Coarse Particles on Daily Mortality in Stockholm, Sweden. Environ. Health Perspect. 2012, 120, 431-436. [CrossRef]

17. Amato, F.; Favez, O.; Pandolfi, M.; Alastuey, A.; Querol, X.; Moukhtar, S.; Bruge, B.; Verlhac, S.; Orza, J.; Bonnaire, N.; et al. Traffic induced particle resuspension in Paris: Emission factors and source contributions. Atmos. Environ. 2016, 129, 114-124. [CrossRef]

18. Basagaña, X.; Jacquemin, B.; Karanasiou, A.; Ostro, B.; Querol, X.; Agis, D.; Alessandrini, E.; Alguacil, J.; Artinano, B.; Catrambone, M.; et al. Short-term effects of particulate matter constituents on daily hospitalizations and mortality in five South-European cities: Results from the MED-PARTICLES project. Environ. Int. 2014, 75, 151-158. [CrossRef]

19. Vlasov, D.; Kosheleva, N.; Kasimov, N. Spatial distribution and sources of potentially toxic elements in road dust and its PM10 fraction of Moscow megacity. Sci. Total Environ. 2020, 761, 143267. [CrossRef]

20. Zhang, J.; Wu, L.; Zhang, Y.; Li, F.; Fang, X.; Mao, H. Elemental composition and risk assessment of heavy metals in the PM10 fractions of road dust and roadside soil. Particuology 2019, 44, 146-152. [CrossRef]

21. Pant, P.; Baker, S.J.; Shukla, A.; Maikawa, C.; Pollitt, K.G.; Harrison, R.M. The PM 10 fraction of road dust in the UK and India: Characterization, source profiles and oxidative potential. Sci. Total Environ. 2015, 531, 445-452. [CrossRef] [PubMed] 
22. Pachón, J.E.; Galvis, B.; Lombana, O.; Carmona, L.G.; Fajardo, S.; Rincón, A.; Meneses, S.; Chaparro, R.; Nedbor-Gross, R.; Henderson, B. Development and Evaluation of a Comprehensive Atmospheric Emission Inventory for Air Quality Modeling in the Megacity of Bogotá. Atmosphere 2018, 9, 49. [CrossRef]

23. Pachon, J.E.; Vanegas, S.; Saavedra, C.; Amato, F.; Silva, L.F.O.; Blanco, K.; Chaparro, R.; Casas, O.M. Evaluation of factors influencing road dust loadings in a Latin American urban center. J. Air Waste Manag. Assoc. 2021, 71, 268-280. [CrossRef]

24. Ramírez, O.; de la Campa, A.M.S.; Amato, F.; Moreno, T.; Silva, L.; de la Rosa, J.D. Physicochemical characterization and sources of the thoracic fraction of road dust in a Latin American megacity. Sci. Total Environ. 2018, 652, 434-446. [CrossRef]

25. Ramírez, O.; da Boit, K.; Blanco, E.; Silva, L. Hazardous thoracic and ultrafine particles from road dust in a Caribbean industrial city. Urban. Clim. 2020, 33, 100655. [CrossRef]

26. Bogotá Cómo Vamos. Informe de Calidad de Vida En Bogotá 2018; Bogotá Cómo Vamos: Bogotá, Colombia, 2019.

27. Secretaría Distrital de Ambiente. Inventario de Emisiones de Bogotá, Contaminantes Atmosféricos 2018; Secretaría Distrital de Ambiente: Bogotá, Colombia, 2020.

28. Ramírez, O.; de la Campa, A.S.; Amato, F.; Catacolí, R.A.; Rojas, N.Y.; de la Rosa, J. Chemical composition and source apportionment of PM10 at an urban background site in a high-altitude Latin American megacity (Bogota, Colombia). Environ. Pollut. 2018, 233, 142-155. [CrossRef] [PubMed]

29. DANE. Omisión Censal: Nivel Municipal y Departamental; DANE: Bogotá, Colombia, 2019.

30. Cuesta-Mosquera, A.P.; Wahl, M.; Acosta-López, J.G.; García-Reynoso, J.A.; Aristizábal-Zuluaga, B.H. Mixing layer height and slope wind oscillation: Factors that control ambient air SO2 in a tropical mountain city. Sustain. Cities Soc. 2019, $52,101852$. [CrossRef]

31. González, C.; Gómez, C.; Rojas, N.; Acevedo, H.; Aristizábal, B. Relative impact of on-road vehicular and point-source industrial emissions of air pollutants in a medium-sized Andean city. Atmos. Environ. 2016, 152, 279-289. [CrossRef]

32. Universidad Nacional de Colombia. Corpocaldas Aplicación de Herramientas de Simulación Atmosférica En El Estudio de La Calidad Del Aire En Manizales_Informe Final Convenio Interadministrativo No. 107-2018; Universidad Nacional de Colombia: Bogotá, Colombia, 2019.

33. Carn, S.A.; Fioletov, V.E.; McLinden, C.; Li, C.; Krotkov, N. A decade of global volcanic SO2 emissions measured from space. Sci. Rep. 2017, 7, srep44095. [CrossRef]

34. Manizales Cómo Vamos. Informe de Calidad de Vida Manizales 2019; Manizales Cómo Vamos: Bogotá, Colombia, 2019.

35. Amato, F.; Pandolfi, M.; Viana, M.; Querol, X.; Alastuey, A.; Moreno, T. Spatial and chemical patterns of PM10 in road dust deposited in urban environment. Atmos. Environ. 2009, 43, 1650-1659. [CrossRef]

36. Trejos, E.M.; Silva, L.F.; Hower, J.C.; Flores, E.M.; González, C.M.; Pachón, J.E.; Aristizábal, B.H. Volcanic emissions and atmospheric pollution: A study of nanoparticles. Geosci. Front. 2021, 12, 746-755. [CrossRef]

37. Murillo, J.H.; Marín, J.F.R.; Álvarez, V.M.; Arias, D.S.; Guerrero, V.H.B. Chemical characterization of filterable PM 2.5 emissions generated from regulated stationary sources in the Metropolitan Area of Costa Rica. Atmos. Pollut. Res. 2017, 8, 709-717. [CrossRef]

38. Reimann, C.; de Caritat, P. Chemical Elements in the Environment. In Factsheets for the Geochemist and Environmental Scientist, 1st ed.; Springer: Berlin/Heidelberg, Germany, 1998; ISBN 978-3-642-72018-5.

39. Rudnick, R.; Gao, S. Composition of the Continental Crust. Treatise Geochem. 2003, 3, 1217-1232. [CrossRef]

40. Sutherland, R.A. Bed sediment-associated trace metals in an urban stream, Oahu, Hawaii. Environ. Earth Sci. 2000, 39, 611-627. [CrossRef]

41. Kaiser, H.F. The varimax criterion for analytic rotation in factor analysis. Psychometrika 1958, 23, 187-200. [CrossRef]

42. Amato, F.; Pandolfi, M.; Alastuey, A.; Lozano, A.; González, J.C.; Querol, X. Impact of traffic intensity and pavement aggregate size on road dust particles loading. Atmos. Environ. 2013, 77, 711-717. [CrossRef]

43. Padoan, E.; Ajmone-Marsan, F.; Querol, X.; Amato, F. An empirical model to predict road dust emissions based on pavement and traffic characteristics. Environ. Pollut. 2017, 237, 713-720. [CrossRef]

44. Kong, S.; Ji, Y.; Lu, B.; Chen, L.; Han, B.; Li, Z.; Bai, Z. Characterization of PM10 source profiles for fugitive dust in Fushun-a city famous for coal. Atmos. Environ. 2011, 45, 5351-5365. [CrossRef]

45. Ramírez, O.; de la Campa, A.M.S.; Sánchez-Rodas, D.; de la Rosa, J.D. Hazardous trace elements in thoracic fraction of airborne particulate matter: Assessment of temporal variations, sources, and health risks in a megacity. Sci. Total Environ. 2020, 710, 136344. [CrossRef]

46. Vega, E.; Mugica, V.; Reyes, E.; Sánchez, G.; Chow, J.; Watson, J. Chemical composition of fugitive dust emitters in Mexico City. Atmos. Environ. 2001, 35, 4033-4039. [CrossRef]

47. Herrera Ardila, M.C. Suelos Derivados de Cenizas Volcánicas En Colombia: Estudio Fundamental e Implicaciones En Ingeniería. Rev. Int. Desastres Nat. Accid. Infraestruct. Civ. 2006, 6, 167.

48. Cheng, Y.; Lee, S.-C.; Gu, Z.; Ho, K.F.; Zhang, Y.; Huang, Y.; Chow, J.C.; Watson, J.; Cao, J.; Zhang, R. PM2.5 and PM10-2.5 chemical composition and source apportionment near a Hong Kong roadway. Particuology 2013, 18, 96-104. [CrossRef]

49. Karanasiou, A.; Diapouli, E.; Cavalli, F.; Eleftheriadis, K.; Viana, M.; Alastuey, A.; Querol, X.; Reche, C. On the quantification of atmospheric carbonate carbon by thermal/optical analysis protocols. Atmos. Meas. Tech. 2011, 4, 2409-2419. [CrossRef]

50. Querol, X.; Viana, M.; Alastuey, A.; Amato, F.; Moreno, T.; Castillo, S.; Pey, J.; de la Rosa, J.D.; de la Campa, A.M.S.; Artinano, B.; et al. Source origin of trace elements in PM from regional background, urban and industrial sites of Spain. Atmos. Environ. 2007, 41, 7219-7231. [CrossRef] 
51. Wiseman, C.L.; Levesque, C.; Rasmussen, P.E. Characterizing the sources, concentrations and resuspension potential of metals and metalloids in the thoracic fraction of urban road dust. Sci. Total Environ. 2021, 786, 147467. [CrossRef]

52. Findeter. Plan Maestro de Movilidad de Manizales; Findeter: Bogotá, Colombia, 2017.

53. Fujiwara, F.; Rebagliati, R.J.; Dawidowski, L.; Gómez, D.; Polla, G.; Pereyra, V.; Smichowski, P. Spatial and chemical patterns of size fractionated road dust collected in a megacitiy. Atmos. Environ. 2011, 45, 1497-1505. [CrossRef]

54. Manno, E.; Varrica, D.; Dongarrà, G. Metal distribution in road dust samples collected in an urban area close to a petrochemical plant at Gela, Sicily. Atmos. Environ. 2006, 40, 5929-5941. [CrossRef]

55. Liu, Y.; Xing, J.; Wang, S.; Fu, X.; Zheng, H. Source-specific speciation profiles of PM2.5 for heavy metals and their anthropogenic emissions in China. Environ. Pollut. 2018, 239, 544-553. [CrossRef] 